\title{
Effect of Changes in Climate and Emissions on Future Sulfate-Nitrate-Ammonium Aerosol Levels in the United States
}

\section{Citation}

Pye, H. O. T., H. Liao, S. Wu, Loretta J. Mickley, Daniel J.Jacob, Daven K. Henze, and J. H.

Seinfeld. 2009. Effect of changes in climate and emissions on future sulfate-nitrate-ammonium aerosol levels in the United States. Journal of Geophysical Research 114(D01205): 1-18.

\section{Published Version}

doi:10.1029/2008JD010701

\section{Permanent link}

http://nrs.harvard.edu/urn-3:HUL.InstRepos:3553964

\section{Terms of Use}

This article was downloaded from Harvard University's DASH repository, and is made available under the terms and conditions applicable to Other Posted Material, as set forth at http:// nrs.harvard.edu/urn-3:HUL.InstRepos:dash.current.terms-of-use\#LAA

\section{Share Your Story}

The Harvard community has made this article openly available.

Please share how this access benefits you. Submit a story.

\section{Accessibility}




\title{
Effect of changes in climate and emissions on future sulfate-nitrate-ammonium aerosol levels in the United States
}

\author{
H. O. T. Pye, ${ }^{1}$ H. Liao, ${ }^{2}$ S. Wu, ${ }^{3,4}$ L. J. Mickley, ${ }^{3}$ D. J. Jacob, ${ }^{3}$ D. K. Henze, ${ }^{5}$ \\ and J. H. Seinfeld ${ }^{1}$
}

Received 1 July 2008; revised 22 September 2008; accepted 7 October 2008; published 9 January 2009.

[1] Global simulations of sulfate, nitrate, and ammonium aerosols are performed for the present day and 2050 using the chemical transport model GEOS-Chem. Changes in climate and emissions projected by the IPCC A1B scenario are imposed separately and together, with the primary focus of the work on future inorganic aerosol levels over the United States. Climate change alone is predicted to lead to decreases in levels of sulfate and ammonium in the southeast U.S. but increases in the Midwest and northeast U.S. Nitrate concentrations are projected to decrease across the U.S. as a result of climate change alone. In the U.S., climate change alone can cause changes in annually averaged sulfate-nitrate-ammonium of up to $0.61 \mu \mathrm{g} / \mathrm{m}^{3}$, with seasonal changes often being much larger in magnitude. When changes in anthropogenic emissions are considered (with or without changes in climate), domestic sulfate concentrations are projected to decrease because of sulfur dioxide emission reductions, and nitrate concentrations are predicted to generally increase because of higher ammonia emissions combined with decreases in sulfate despite reductions in emissions of nitrogen oxides. The ammonium burden is projected to increase from 0.24 to $0.36 \mathrm{Tg}$, and the sulfate burden to increase from 0.28 to $0.40 \mathrm{Tg} \mathrm{S}$ as a result of globally higher ammonia and sulfate emissions in the future. The global nitrate burden is predicted to remain essentially constant at $0.35 \mathrm{Tg}$, with changes in both emissions and climate as a result of the competing effects of higher precursor emissions and increased temperature.

Citation: Pye, H. O. T., H. Liao, S. Wu, L. J. Mickley, D. J. Jacob, D. K. Henze, and J. H. Seinfeld (2009), Effect of changes in climate and emissions on future sulfate-nitrate-ammonium aerosol levels in the United States, J. Geophys. Res., 114, D01205, doi:10.1029/2008JD010701.

\section{Introduction}

[2] Particulate matter is an important constituent of the atmosphere responsible for negative health impacts [e.g., Dockery et al., 1993], reductions in visibility, and changes in climate [Intergovernmental Panel on Climate Change (IPCC), 2007]. Atmospheric concentrations of aerosols will change in the future as climate and aerosol precursor emissions change. Nitrate $\left(\mathrm{NO}_{3}^{-}\right)$, ammonium $\left(\mathrm{NH}_{4}^{+}\right)$, and sulfate $\left(\mathrm{SO}_{4}^{2-}\right)$ are significant constituents of particulate matter (PM), forming mainly from gas-phase precursors.

\footnotetext{
${ }^{1}$ Department of Chemical Engineering, California Institute of Technology, Pasadena, California, USA.

${ }^{2}$ State Key Laboratory of Atmospheric Boundary Layer Physics and Atmospheric Chemistry, Institute of Atmospheric Physics, Chinese Academy of Sciences, Beijing, China.

${ }^{3}$ School of Engineering and Applied Sciences and Department of Earth and Planetary Sciences, Harvard University, Cambridge, Massachusetts, USA.

${ }^{4}$ Now at Michigan Technological University, Houghton, Michigan, USA.

${ }^{5}$ Earth Institute, Columbia University, New York, New York, USA.
}

Copyright 2009 by the American Geophysical Union. 0148-0227/09/2008JD010701\$09.00
[3] In the absence of changes in aerosol precursor emissions, changes in climate alone will influence future aerosol levels. For example, alterations in wind speed, precipitation, and boundary layer height can translate into changes in stagnation and ventilation [Leung and Gustafson, 2005]. Mickley et al. [2004] showed that a decrease in the number of cyclones tracking over southern Canada has important implications for increased stagnation in the Midwest and northeast U.S. during summer. Dawson et al. [2007] demonstrated that perturbations to present-day temperature, wind speed, absolute humidity, mixing height, and precipitation can all significantly affect $\mathrm{PM}_{2.5}$ (particulate matter with diameter $<2.5 \mu \mathrm{m}$ ).

[4] Surface temperatures are generally projected to be higher in the future with particularly strong warming over continents [IPCC, 2007]. Temperature influences $\mathrm{PM}_{2.5}$ concentrations through its effect on precursor emissions rates, chemical reaction rates, and gas-aerosol partitioning of semi-volatile species. For example, increasing temperature can lead to a reduction in nitrate aerosol mass as a result of ammonium and nitrate partitioning to the gas-phase [Dawson et al., 2007]. Changes in gas-aerosol partitioning of nitrate/nitric acid will also affect total nitrate (nitrate 
aerosol and nitric acid) as a result of the different wet and dry deposition rates of the two species [Aw and Kleeman, 2003]. In contrast, higher temperatures can result in increased gas-phase reaction rates and oxidant concentrations, which can lead to higher sulfate concentrations [Dawson et al., 2007; Liao et al., 2006; Rae et al., 2007]. Jacob and Winner [2009] present a review of studies examining the effect of changes in climate on ozone and PM.

[5] Future PM concentrations in the U.S. will be influenced not only by changes in domestic emissions but by changes in other regions as well. Transpacific transport of Asian pollution has been shown to contribute to sulfate in the U.S. [Benkovitz et al., 2006; Heald et al., 2006; Park et al., 2006; Chin et al., 2007; Koch et al., 2007; Liu et al., 2008], and the preferential export of sulfur dioxide $\left(\mathrm{SO}_{2}\right)$ from Asia over ammonia/ammonium leads to slight decreases in U.S. nitrate [Park et al., 2004].

[6] This study is a companion study to the work of $\mathrm{Wu}$ et al. [2008], which investigated the effects of projected climate and emissions changes on tropospheric ozone. This work investigates the potential effects of projected climate and emission changes on sulfate-nitrate-ammonium aerosol levels, with a focus on the United States. Future climate, for year 2050, is simulated with the Goddard Institute for Space Studies (GISS) general circulation model (GCM) version III [Rind et al., 2007]. IPCC emission scenario A1B [Nakicenovic and Swart, 2000] is adopted. Eventually, multiple emissions scenarios will be tested with the GISS/ GEOS-Chem framework. Warming under A1B is generally predicted to be more pronounced than under B1 and less pronounced than under $\mathrm{A} 2$ since $\mathrm{A} 1 \mathrm{~B}$ represents rapid growth with balanced energy use. However, for year 2050, A1B was found to have the highest multi-model mean surface warming (compared to B1 and A2) in the IPCC Fourth Assessment Report [IPCC, 2007].

[7] The global meteorological fields from the GISS model provide the conditions for input into the atmospheric chemical transport model GEOS-Chem for both present day (1999-2001) and years 2049-2050. Effects of climate change alone, emission changes alone, and both climate and emissions changes in concert on sulfatenitrate-ammonium levels are simulated. While the focus is on a specific future emission scenario, the mechanistic understanding of the magnitudes and directions of the projected changes will allow for extrapolation of the effects to other potential emissions scenarios such as mitigation strategies for air quality attainment. Because of the nonlinear nature of secondary inorganic aerosol formation, particularly for nitrate, the change in sulfate concentrations due to changes in sulfur dioxide emissions is likely to be the most robust and generally applicable sensitivity.

[8] Secondary organic aerosol (SOA) is another important component of atmospheric aerosols and should be included in an examination of $\mathrm{PM}_{2.5}$. GEOS-Chem currently has the capability to treat SOA from biogenics [Chung and Seinfeld, 2002; Henze and Seinfeld, 2006] and aromatics [Henze et al., 2008a]. Studies indicate the amount of SOA predicted by models severely underestimates the actual amount present in the atmosphere [de Gouw et al., 2005, 2008; Heald et al., 2005; Volkamer et al., 2006]. The treatment of SOA will be part of a future work that focuses on improving the underlying SOA model in addition to examining the effects of changes in climate and emissions on future organic aerosol levels.

[9] The methods and model setup used to examine sulfate, nitrate, and ammonium aerosols are discussed in section 2 followed by present-day predictions of those aerosols (section 3). Section 4 presents predictions for future inorganic aerosol levels over the U.S. due to changes in climate alone, emission changes alone, and combined climate and emission changes. Global budgets for the present day and future can be found in section 5, and section 6 discusses some implications of changes in climate and emissions for sulfur outflow from the U.S.

\section{Methods}

\subsection{GEOS-Chem/GISS Model Setup}

[10] The atmospheric chemical transport model, GEOSChem v.7-4-11 (http:/www-as.harvard.edu/chemistry/trop/ geos), is employed with GISS GCM III [Rind et al., 2007] meteorological data. The models use 23 hybrid sigmapressure levels with the lowest layers extending up to 200, 500, and $900 \mathrm{~m}$ for a surface pressure of $1010 \mathrm{hPa}$. A comparison of present-day GISS Model E (similar to Model III) predictions of precipitation, specific humidity, temperature, and other meteorological variables to observations can be found in the work of Schmidt et al. [2006], and Rind et al. [2007] compare Model E and Model III meteorology using several tracers. The analysis of Rind et al. [2007] includes the use of a radon tracer as a diagnostic of precipitation. The interface between GEOS-Chem and the GISS meteorological fields is described by Wu et al. [2007], and the same meteorology as used in the work of $\mathrm{Wu}$ et al. [2008] is used here. Present-day meteorological conditions in the GISS GCM are simulated with greenhouse gas levels corresponding to years 1999-2001. Year 2049-2051 climate is obtained from a dynamic GCM simulation in which $\mathrm{CO}_{2}$ and other greenhouse gases follow the IPCC A1B scenario. Although changes in aerosols and ozone could have significant influences on climate by the end of the 21 st century [Levy et al., 2008], those effects are not considered here in the GISS simulations. $\mathrm{CO}_{2}$ is calculated to reach $522 \mathrm{ppm}$ by 2050. The GISS GCM yields a global mean surface temperature increase of $1.6 \mathrm{~K}$ and an increase of $8 \%$ in annual mean precipitation for 2000-2050 [Wu et al., 2008].

[11] The GEOS-Chem simulations use a global resolution of $4^{\circ}$ latitude by $5^{\circ}$ longitude with 23 vertical layers and include coupled ozone- $\mathrm{NO}_{x}$-hydrocarbon and aerosol chemistry [Bey et al., 2001; Park et al., 2004; Liao et al., 2007] with all tracers listed by Liao et al. [2007]. Changes in ozone and aerosol precursor emissions are considered for both present-day and future (2050) scenarios. $\mathrm{SO}_{2}$ is both directly emitted and produced by atmospheric oxidation of dimethyl sulfide (DMS); $\mathrm{SO}_{2}$ reacts in either gas or aqueous phases to form sulfate. A minor sulfate formation pathway on fine sea salt aerosol as a result of $\mathrm{SO}_{2}$ reacting with ozone is also considered [Alexander et al., 2005]. The global burden of sulfate on coarse sea salt aerosol is expected to be small and its lifetime short [Alexander et al., 2005], so the production of sulfate on coarse sea salt is neglected in the analysis. Ammonium nitrate aerosol forms from gas-aerosol partitioning of ammonia and nitric acid [Seinfeld and Pandis, 2006]. Ammonia is emitted directly 
Table 1. Present-Day and 2050 Predicted (IPCC A1B Scenario) Emissions of Aerosol Precursors

\begin{tabular}{|c|c|c|c|c|}
\hline \multirow[b]{2}{*}{ Species } & \multicolumn{2}{|c|}{ Global } & \multicolumn{2}{|c|}{ U.S. ${ }^{\text {a }}$} \\
\hline & 2000 & 2050 & 2000 & 2050 \\
\hline \multicolumn{5}{|l|}{$\mathrm{NO}_{x}(\mathrm{Tg} \mathrm{N} / \mathrm{yr})$} \\
\hline Aircraft & 0.5 & 0.5 & 0.11 & 0.11 \\
\hline Anthropogenic & 23.7 & 47.9 & 6.11 & 3.8 \\
\hline Biomass burning & 6.5 & 8.1 & 0.05 & 0.08 \\
\hline Biofuel & 2.2 & 2.1 & 0.01 & 0.01 \\
\hline Fertilizer & 0.5 & 0.9 & 0.05 & 0.06 \\
\hline \multicolumn{5}{|l|}{$\mathrm{NH}_{3}(\mathrm{Tg} \mathrm{N} / \mathrm{yr})$} \\
\hline Anthropogenic & 33.3 & 50.5 & 2.11 & 3.31 \\
\hline Biomass burning & 5.9 & 6.1 & 0.05 & $0 .($ \\
\hline Biofuel & 1.6 & 1.7 & 0.18 & 0.16 \\
\hline Natural & 14.2 & 14.2 & 0.58 & 0.58 \\
\hline \multicolumn{5}{|l|}{$\mathrm{SO}_{2}(\mathrm{Tg} \mathrm{S} / \mathrm{yr})$} \\
\hline Aircraft & 0.1 & 0.1 & 0.02 & 0.02 \\
\hline Anthropogenic & 61.2 & 81.8 & 9.24 & 2.35 \\
\hline Biomass burning & 1.2 & 2.0 & 0.01 & 0.03 \\
\hline Biofuel & 0.3 & 0.3 & $<0.01$ & $<0.01$ \\
\hline Volcanoes & 5.5 & 5.5 & 0.07 & 0.07 \\
\hline Ships & 4.2 & 5.4 & - & \\
\hline \multicolumn{5}{|l|}{$\mathrm{SO}_{4}{ }^{2-}(\mathrm{Tg} \mathrm{S} / \mathrm{yr})$} \\
\hline Anthropogenic & 2.0 & 2.6 & 0.16 & 0.04 \\
\hline
\end{tabular}

${ }^{\mathrm{a} U}$ U.S. emissions for the contiguous states only.

and does not participate in gas-phase chemistry, although it is removed by wet and dry deposition. Nitric acid is formed from gas-phase nitrogen oxides $\left(\mathrm{NO}_{x}\right)$, which are mostly of anthropogenic origin but have important natural sources, including lightning and soils. In addition to its daytime photooxidation source, nitric acid $\left(\mathrm{HNO}_{3}\right)$ is produced in heterogeneous nighttime reactions involving $\mathrm{N}_{2} \mathrm{O}_{5}, \mathrm{NO}_{3}$, and $\mathrm{NO}_{2}$ [Jacob, 2000; Martin et al., 2003; Evans and $J a c o b, 2005]$. In addition to these heterogeneous reactions, aerosols may influence the gas phase by modifying photolysis rates [Martin et al., 2003]. Nitric acid, sulfate, nitrate, and ammonium are assumed to be completely soluble in the cloud condensate phase in convective updrafts and rainout and washout. The representation of dry deposition follows a resistance in series scheme [Wesely, 1989], with the surface resistances for sulfate, nitrate, and ammonium aerosols following the work of Zhang et al. [2001].

\subsection{Emissions}

[12] Present-day emissions of ozone and aerosol precursors in GEOS-Chem generally follow Wu et al. [2007] with fossil fuel emissions outside the U.S. updated to 1998. The present-day ammonia emission inventory is based on the work of Bouwman et al. [1997], as implemented by Park et al. [2004]. Most ammonia is anthropogenic in origin and results from domesticated animals and agricultural operations [Park et al., 2004]. Ammonia emissions are not calculated on-line as a function of temperature in this model, but do have an imposed seasonality that was determined as a function of temperature for one base year [Park et al., 2004]. Sulfur emission sources from the Global Emission Inventory Activity (GEIA) are also described by Park et al. [2004] and now include emissions from ships [Corbett et al., 1999]. Bey et al. [2001] and references therein provide information on the anthropogenic $\mathrm{NO}_{x}$ emission inventories. Present-day methane levels in the model are based on observations and are set to $1750 \mathrm{ppb}$ with a 5\% inter-hemispheric gradient [Wu et al., 2008]. Future emissions follow the Integrated Model to Assess the
Greenhouse Effect (IMAGE) model for IPCC scenario A1B [Streets et al., 2004] and are implemented using prescribed growth factors for different regions, species, and sources. Table 1 shows anthropogenic emissions for the present day and year 2050 (following IPCC A1B). The future (20492051) methane level in GEOS-Chem is set to $2400 \mathrm{ppb}$ for simulations in which changes in anthropogenic emissions are considered.

[13] Natural emissions of DMS, $\mathrm{NO}_{x}$ from lightning and soils, sea salt, and biogenic hydrocarbons depend on meteorology and are computed online in the model. Natural emissions predicted for both the present-day and future climate are given in Table 2. DMS emissions [Saltzman et al., 1993; Nightingale et al., 2000] are treated as a function of wind speed, and present-day climatological sea surface temperatures and DMS ocean concentrations are used. Lightning $\mathrm{NO}_{x}$ emissions are parameterized based on convective cloud-top height [Price and Rind, 1992; Wang et al., 1998] and are distributed according to Pickering et al. [1998]. Lightning $\mathrm{NO}_{x}$ emissions are scaled to produce $4.8 \mathrm{Tg} \mathrm{N}$ for year 2000. Soil $\mathrm{NO}_{x}$ emissions are calculated as described by Wang et al. [1998] considering changes in temperature, wind speed, and precipitation [Yienger and Levy, 1995]. Sea salt is emitted in both fine and coarse sizes as a function of wind speed [Alexander et al., 2005; Monahan et al., 1986]. Biogenic hydrocarbon emissions include those from isoprene [Guenther et al., 1995], monoterpenes [Guenther et al., 1995], acetone [Jacob et al., 2002], and other alkenes (scaled to isoprene). Because of the relatively coarse resolution of surface wind speed and the particularly strong dependence of dust emissions on wind speed, emissions of dust are not included. Changes in land use and biomass burning due to climate change are also not considered.

\subsection{Inorganic Aerosol Model}

[14] ISORROPIA II [Fountoukis and Nenes, 2007] is implemented in GEOS-Chem to compute gas-aerosol equilibrium partitioning of nitric acid and ammonia. Particles in this study are not size-resolved; however, they can be generally assumed to represent $\mathrm{PM}_{2.5}$ since formation of sulfate-nitrate-ammonium on coarse mode sea salt and dust is excluded. Submicrometer-sized particles are likely to reach gas-aerosol equilibrium on time-scales less than the 1 hour computational time step used here [Meng and Seinfeld, 1996].

[15] Sodium and chloride from accumulation mode sea salt are considered in the gas-aerosol equilibrium along with

Table 2. Predicted Changes in Natural Emissions Due to Predicted Climate Change (IPCC A1B Scenario)

\begin{tabular}{|c|c|c|c|c|}
\hline \multirow[b]{2}{*}{ Species } & \multicolumn{2}{|c|}{ Global } & \multicolumn{2}{|c|}{ U.S. $^{\text {a }}$} \\
\hline & 2000 & 2050 & 2000 & 2050 \\
\hline DMS (Tg S/yr) & 16.0 & 16.0 & - & 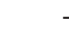 \\
\hline \multicolumn{5}{|l|}{$\mathrm{NO}_{x}(\mathrm{Tg} \mathrm{N} / \mathrm{yr})$} \\
\hline Lightning & 4.7 & 5.6 & 0.08 & 0.09 \\
\hline Soil & 5.9 & 6.4 & 0.36 & 0.40 \\
\hline \multicolumn{5}{|l|}{ Sea salt (Tg/yr) } \\
\hline Accumulation & 71.5 & 72.5 & - & \\
\hline Coarse & 5322.0 & 5395.3 & - & \\
\hline Biogenic $\mathrm{HCs}^{\mathrm{b}}(\mathrm{Tg} \mathrm{C} / \mathrm{yr})$ & 631.9 & 778.2 & 42.37 & 52.06 \\
\hline
\end{tabular}




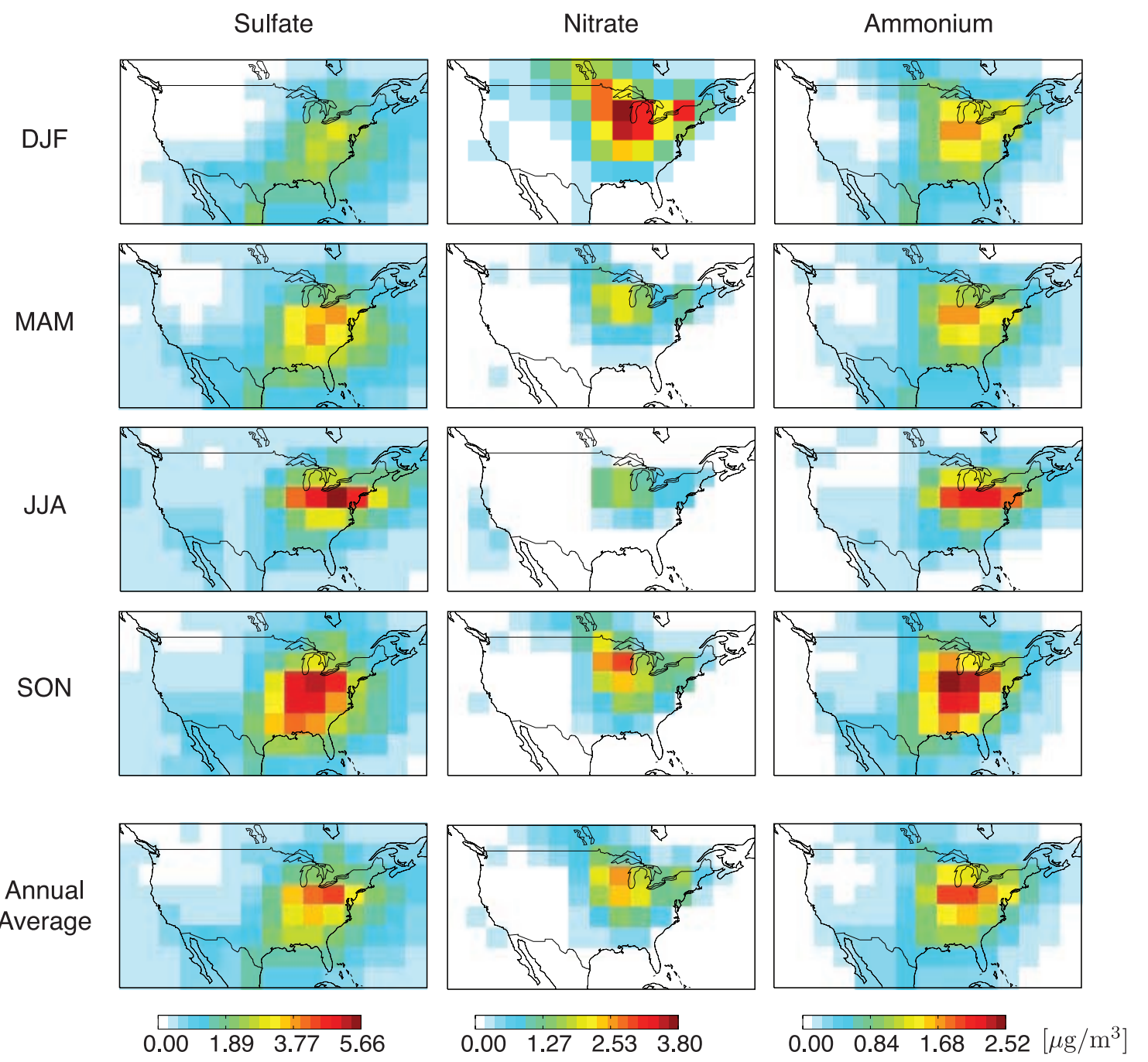

Figure 1. Present-day (year 1999-2001 meteorology and emissions) predictions of surface-level sulfate, nitrate, and ammonium aerosols for the United States. Each of the first four rows is a seasonal average (DJF, MAM, JJA, and SON), and the bottom row is the annual average over 3 years.

sulfate, nitrate, and ammonium. Calcium, magnesium, and potassium concentrations are not considered in the present study because of the issues with dust emissions previously mentioned. All inorganic aerosols are assumed to exist on the upper, metastable branch of the hygroscopic hysterisis curve. Although this assumption may not hold at higher altitudes in the free troposphere [Wang et al., 2008], since the focus of this study is mainly on surface-level concentrations, where humidities reach high values on a daily basis, the metastable assumption is acceptable.

\section{Present-Day Predictions}

\subsection{Sulfate}

[16] Present-day sulfate concentrations across the United States vary seasonally (Figure 1), as governed by changes in photochemistry and wet removal with influences from transport. $\mathrm{SO}_{2}$ emissions exhibit little seasonality with the highest emissions in the eastern United States. Sulfate concentrations are lowest in December-January-February (DJF) when oxidants/photochemistry are lowest. In MarchApril-May (MAM), higher levels of photochemistry lead to enhanced levels of sulfate compared to those in DJF, but increased precipitation and transport keeps sulfate concentrations at moderate levels. In-cloud sulfate production near the surface via reaction with $\mathrm{H}_{2} \mathrm{O}_{2}$ is highest in MAM because of slightly more cloud cover than in JJA, but aqueous production is still significantly less than production from gas-phase $\mathrm{OH}$ reaction. The most active photochemistry occurs during June-July-August (JJA), the season when precipitation is particularly intense in the Southeast for the meteorology used here. As a result, sulfate concentrations are significant but tend to be more localized than in MAM. September-October-November (SON) is characterized by intermediate, but still significant, oxidant levels. While production rates of sulfate in MAM and SON are similar, as a result of low precipitation, sulfate concentrations are actually higher in SON than JJA or MAM for some locations like the Southeast.

\subsection{Nitrate}

[17] Anthropogenic $\mathrm{NO}_{x}$ emissions, like anthropogenic $\mathrm{SO}_{2}$, exhibit little seasonal variation and are highest in the eastern United States. Soil $\mathrm{NO}_{x}$ emissions peak in JJA over 
the middle of the United States. Soil $\mathrm{NO}_{x}$ is potentially more important in the western United States where anthropogenic $\mathrm{NO}_{x}$ emissions are lower.

[18] Nitrate aerosol concentrations (Figure 1) can be explained by the combined effects of temperature, precipitation, and photochemistry. Oxidant levels and wet deposition determine the amount of total nitrate $\left(\mathrm{HNO}_{3}+\mathrm{NO}_{3}^{-}\right)$ available. Since $\mathrm{HNO}_{3}$ undergoes efficient dry deposition when compared to that for particles, gas-aerosol partitioning also influences total nitrate levels. Maximum predicted nitrate aerosol surface concentrations in the United States lie north and west of the main anthropogenic $\mathrm{NO}_{x}$ source region in the Northeast, reflecting the role of ammonia emissions in the Midwest. As a result, nitrate formation in the Midwest tends to be nitric acid-limited [Park et al., 2004] as diagnosed by the gas ratio [Ansari and Pandis, 1998] which is the free ammonia $\left(\left[\mathrm{NH}_{3}\right]+\left[\mathrm{NH}_{4}^{+}\right]-2 \times\left[\mathrm{SO}_{4}^{2-}\right]\right)$ divided by total nitrate $\left(\left[\mathrm{HNO}_{3}\right]+\left[\mathrm{NO}_{3}^{-}\right]\right)$expressed in molar concentration units. The Northeast tends to be ammonialimited because of higher sulfate concentrations and lower ammonia emissions.

[19] The highest nitrate aerosol $\left(\mathrm{NO}_{3}^{-}\right)$concentrations are predicted to occur in winter because of low temperatures and low sulfate concentrations. Total (gas + aerosol) nitrate is high in JJA, but both high temperatures and precipitation lead to the lowest nitrate aerosol concentrations in this season. Like MAM, SON is characterized by both intermediate photochemistry and temperatures. Because precipitation in SON is relatively low, which reduces loss of total nitrate by wet deposition, SON nitrate aerosol concentrations are significant but not as high as those in DJF.

\subsection{Ammonium}

[20] Unlike $\mathrm{NO}_{x}$ and $\mathrm{SO}_{2}$, anthropogenic ammonia emissions, mostly from domesticated animals and fertilizer use, exhibit pronounced seasonality with the highest and lowest emissions occurring in JJA and DJF, respectively. $\mathrm{NH}_{3}$ emissions from sources such as crops and soils are also largest in JJA and smallest in DJF. Spatially, emissions are highest in the eastern U.S., but also significant in the West. Ammonium aerosol concentrations (Figure 1) follow those of sulfate and nitrate, with which they are chemically linked.

\subsection{Comparison to Measurements}

[21] To evaluate the predictions of present-day concentrations of sulfate, nitrate, and ammonium, simulations are compared to the Clean Air Status and Trends Network (CASTNET, http://www.epa.gov/castnet/) measurements (Figure 2). CASTNET provides concentrations of sulfate, nitrate, nitric acid, and ammonium as well as estimates of dry deposition velocities and fluxes. While some GEOSChem grid cells do not contain any CASTNET sites, a number of grid cells have 5 or more CASTNET sites each over the eastern United States. Seasonal CASTNET averages are created from monthly data from years 1998-2001 to represent a climatological mean. For the purposes of analysis, an arbitrary division between eastern and western United States is made at $92.5^{\circ} \mathrm{W}$ longitude which runs from Minnesota to Louisiana. The Interagency Monitoring of Protected Visual Environments (IMPROVE) network also provides sulfate and nitrate concentration measurements, and Liao et al. [2007] present a comparison of sulfate concentrations predicted by GEOS-Chem to IMPROVE observations. CASTNET measurements are chosen here for comparison because of their more complete spatial coverage over the eastern U. S. where the highest sulfate and nitrate aerosol concentrations occur.

[22] Inorganic aerosol concentrations are generally underpredicted over the entire United States. However, nitrate is typically over-predicted in the eastern U.S. (e.g., JJA). The normalized mean bias for the entire U.S. (NMB $=\sum_{i=1}^{N}\left(P_{i}-\right.$ $\left.O_{i}\right) / \sum_{i=1}^{N}\left(O_{i}\right) * 100 \%$, where $P_{i}$ is the prediction and $O_{i}$ is the observation) ranges from $-50 \%$ in JJA to $-17 \%$ in SON for sulfate and $-41 \%$ in MAM to $-6 \%$ in DJF for nitrate. The normalized mean bias for ammonium ranges from $-32 \%$ in JJA to $+5 \%$ in SON. The correlation between nitrate observations and predictions is the weakest of the inorganic aerosols with the poorest correlation in JJA. Nitrate aerosol concentrations in the western U.S. in JJA are significantly under-predicted.

[23] Some under-prediction could result from coarse $(>2.5 \mu \mathrm{m}$ diameter) material being captured in the CASTNET samples. However, Morris et al. [2005] estimate that most secondary nitrate $(>90 \%)$ can be assumed to be present in fine particles in the rural West, although exceptions can occur. In addition, nitrate may volatilize from the Teflon filters used in CASTNET [Ames and Malm, 2001]. As a result, CASTNET sites may under-report or over-report $\mathrm{PM}_{2.5}$ depending on the amount of coarse aerosol present and the extent of nitrate volatilization.

[24] Examining data from five individual CASTNET sites in the western United States (mostly Southern California) reveals that both gas-phase nitric acid and total nitrate are under-predicted, which could be a result of (1) insufficient formation of $\mathrm{HNO}_{3}$ in the gas phase or (2) insufficient partitioning of $\mathrm{HNO}_{3}$ to particulate nitrate resulting in total nitrate being preferentially lost via efficient dry deposition of $\mathrm{HNO}_{3}$. Dry deposition velocities predicted by the model at these 5 western sites in JJA have a normalized mean bias of $+88 \%$ compared to the CASTNET data. A sensitivity study, performed in the West for JJA in which the dry deposition velocity of $\mathrm{HNO}_{3}$ was capped at $1.5 \mathrm{~cm} / \mathrm{s}$, however, did not produce a significant improvement in nitrate aerosol predictions, indicating that under-prediction of nitrate aerosol is not a result of $\mathrm{HNO}_{3}$ dry deposition alone.

[25] Other studies using different global chemical transport models and different thermodynamic models for inorganic aerosols also reveal significant underestimates in fine mode nitrate in Southern California [Mhyre et al., 2006; Bauer et al., 2007]. GEOS-Chem simulations with an inorganic aerosol model based on MARS-A and GEOS assimilated meteorology at a finer resolution also exhibit an underestimate [Park et al., 2006]. Some models predict significant coarse-mode nitrate in Southern California, but the IMPROVE sites show significant fine-mode nitrate (on the order of $1 \mu \mathrm{g} / \mathrm{m}^{3}$ or more) is present in the vicinity of Southern California [Liao et al., 2007].

[26] Nitrate aerosol formation is particularly sensitive to ammonia emissions [e.g., Bauer et al., 2007], suggesting that inaccuracy in the $\mathrm{NH}_{3}$ inventory may be a factor in model under-predictions. Yu et al. [2005] found that total nitrate, total ammonia $\left(\mathrm{NH}_{3}+\mathrm{NH}_{4}^{+}\right)$, and sulfate strongly influence nitrate predictions and that errors in total ammonia 

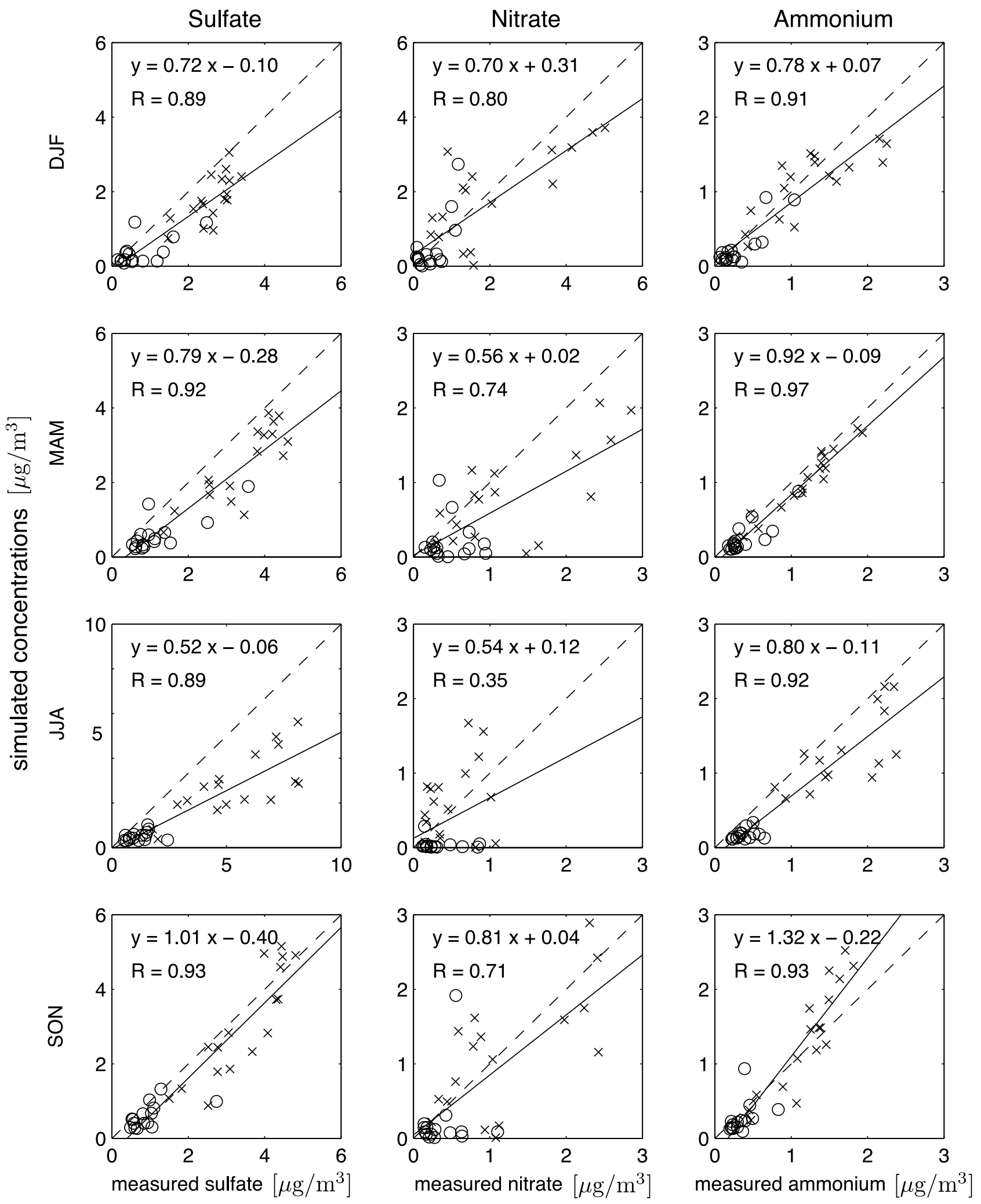

Figure 2. Present-day predictions of sulfate, nitrate, and ammonium aerosols compared to CASTNET observations. Simulated values are seasonal averages for the 3-year period 1999-2001. CASTNET measured values are converted to model resolution for comparison and are seasonally averaged over 1998-2001. Circles represent western U.S. sites (west of $92.5^{\circ} \mathrm{W}$ ), and crosses represent eastern U.S. sites. Also shown is the $1: 1$ line (dashed) and linear fit (solid line and equation). $R$ is the correlation coefficient between simulated and measured concentrations. 

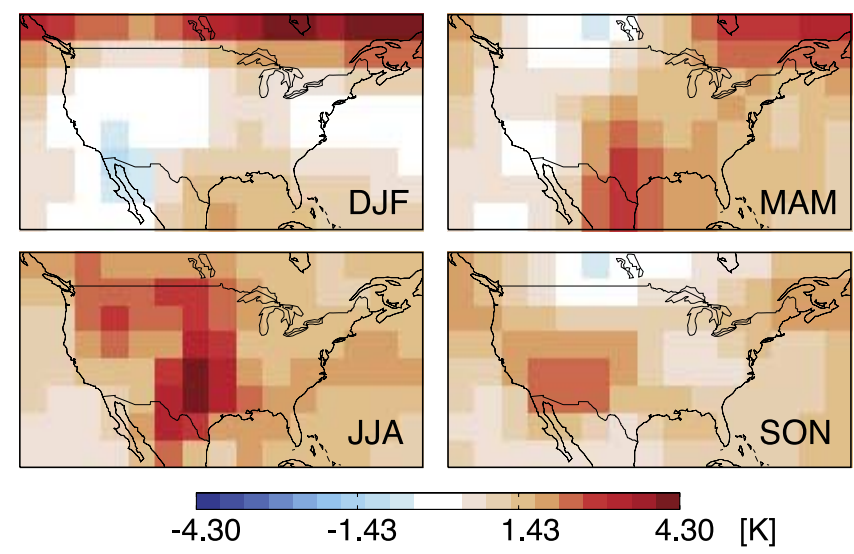

Figure 3. Predicted change in U.S. surface temperature from the present day (1999-2001) to future (2049-2051).

were more influential in this regard than errors in sulfate. Also, Karydis et al. [2007] noted that modest errors in ammonium concentrations can be associated with significant errors in nitrate predictions. The $\mathrm{NH}_{3}$ emissions inventory of Bouwman et al. [1997] used here reports a global uncertainty of $\pm 25 \%$, and individual seasonal and regional uncertainties may be considerably higher. Some studies examining the validity of ammonia emissions inventories have focused mainly on the eastern United States [Mendoza-Dominguez and Russell, 2001; Gilliland et al., 2003; Pinder et al., 2006]. Gilliland et al. [2006] investigated seasonal allocations of the EPA National Emission Inventory (NEI) 2001 inventory and indicated that summer $\mathrm{NH}_{3}$ emissions are likely underestimated to a greater extent in the West than the East.

[27] Additional box model calculations were performed here using conditions representative of summer in Southern California to determine the extent to which errors in predicted total ammonia and total nitrate could be responsible for under-predictions in nitrate aerosol. The analysis indicates that both total nitrate and total ammonia would have to be more than a factor of five higher than current model predictions to obtain nitrate levels consistent with CASTNET data. It is unlikely that emissions inventories of ammonia and $\mathrm{NO}_{x}$ in Southern California during the summer are low by this much. If total nitrate levels produced by the model were correct, then total $\mathrm{NH}_{3}$ (and probably ammonia inventories) would have to be more than a factor of 10 higher than current predictions, to produce simulations consistent with CASTNET observations in Southern California. The EPA NEI for ammonia has been shown to be too high for use in GEOS-Chem [Gilliland et al., 2003; Henze et al., 2008b], and errors in the ammonia inventory are probably not the primary reason for inaccuracies in nitrate predictions based on the sensitivity analysis performed. Nitrate under-prediction may result, at least in part, from a lack of representation of some processes in the model such as interaction with dust and organics [Ansari and Pandis, 2000]. Since regional models can capture the high nitrate concentrations in the Los Angeles basin [Kleeman and Cass, 2001], a global model, even at $1^{\circ}$ by $1^{\circ}$ resolution [Park et al., 2006], may be too coarse to represent nitrate formation in Southern California.
[28] Since this work is primarily directed toward examining changes in aerosol concentrations as a result of future climate change, the underestimate in present-day nitrate in the western U.S. does not compromise conclusions regarding the direction in which inorganic aerosol levels are likely to change in the future, but is an important issue to address in future work.

\section{Predictions of Future Inorganic Aerosol Levels Over the U.S.}

[29] Changes in sulfate, nitrate, and ammonium aerosol concentrations due to changes in climate and emissions are now examined. Section 4.1 addresses how projected changes in meteorology from 2000 to 2050 are predicted to affect sulfate, nitrate, and ammonium aerosol levels with anthropogenic emissions held at present-day values. Section 4.2 discusses the effect of climate change with anthropogenic emissions at future levels. Section 4.3 describes effects of changes in anthropogenic emissions with climate held at present-day conditions, and changes in climate and emissions together are addressed in section 4.4.

\subsection{Effect of Changes in Climate Alone}

[30] Climate change alone will influence future aerosol concentrations through modifications of gas-phase chemistry, transport, removal, and natural emissions. Most predicted changes in natural emissions over the 50 -year period considered here are relatively modest (Table 2 ), except for lightning $\mathrm{NO}_{x}$ and biogenic hydrocarbons, both of which influence gas-phase tropospheric chemistry. Note that natural ammonia emissions are assumed to be independent of meteorological conditions.

[31] Meteorology influences aerosol concentrations through changes in temperature, precipitation, planetary boundary layer depth (PBL depth), transport, humidity, and oxidant levels. In some seasons, certain effects appear to dominate, but generally, changes in concentrations result from multiple climatic changes. Temperature generally increases $1-2 \mathrm{~K}$ between 2000 and 2050 in all seasons over the U.S. with increases in JJA over Texas being the largest and statistically significant (at the 5\% level) (Figure 3). All tests of statistical significance were performed using 10 years of present day (2000) and 10 years of future (2050) meteorology although GEOS-Chem simulations only use 3 years for the present day and 3 years for the future. About $1 \mathrm{~K}$ of cooling is shown for DJF in the southwest U.S. as a result of interannual variability and a relatively cold winter in 2051. The cooling during DJF is not found in the trend using 10 years of present-day and future data and is not statistically significant. Although the warming in DJF and JJA over the U.S. is generally statistically significant, the warming in MAM and SON is not statistically significant (at 5\%). Higher specific humidities are predicted over the U.S. in the future as relative humidity is expected to remain roughly constant [Held and Soden, 2000].

[32] Precipitation trends shown in Figure 4 for three years of the present day and future are generally consistent with the trends using 10 years of present-day and future GISS meteorology. However, not all changes in precipitation are significant at the $5 \%$ level. Predicting future rainfall over mid-latitudes is difficult, as it involves two competing 
(a) Precipitation Change
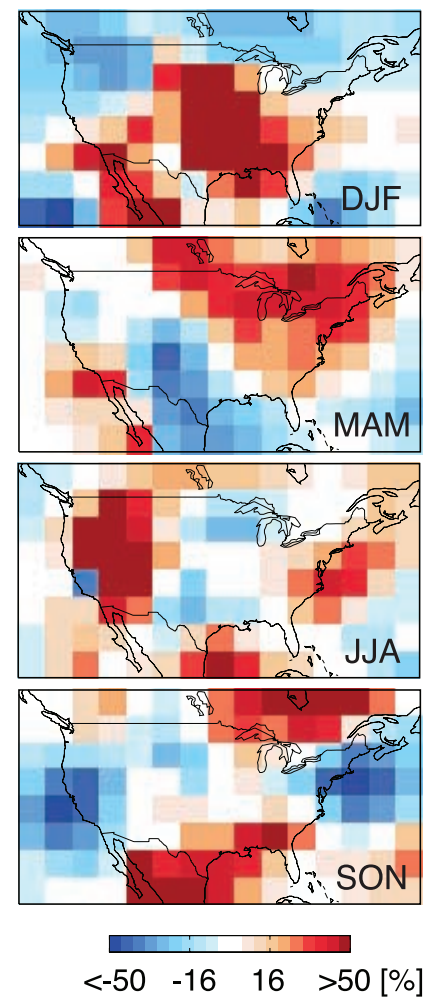

(b) PBL Depth Change
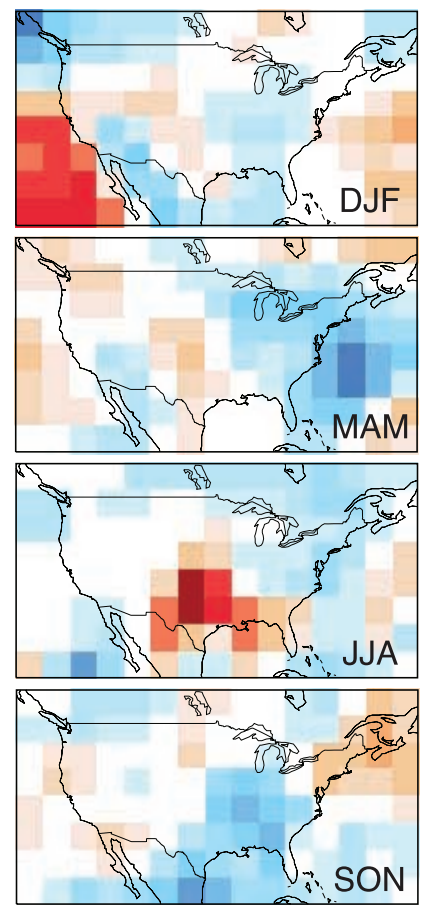

$\begin{array}{llll}-30 & -10 & 10 & 30[\%]\end{array}$

Figure 4. Predicted change in precipitation and afternoon planetary boundary layer (PBL) depth between the present day (1999-2001) and future (2049-2051). The change is expressed as percentage change relative to present day.

factors: (1) increased specific humidity in a warmer climate, which increases rainfall and (2) increased atmospheric stability due to heating aloft which decreases rainfall. Precipitation is predicted to generally increase (Figure 4), especially for DJF and MAM over the eastern U.S., reflecting changes in both large-scale and convective precipitation. DJF and MAM precipitation increases are roughly on the order of $1 \mathrm{~mm} /$ day which is more than a $50 \%$ increase in DJF and about a $20-30 \%$ increase in MAM. The increase in precipitation over the midwest in DJF is consistent with the trend using 10 years of present-day and 10 years of future GISS meteorology and statistically significant (at 5\%). Convective precipitation is largest in JJA and usually highest in the southeast during all seasons. Changes in convective precipitation may be more important than changes in large-scale precipitation as convective storms are generally short-lived and do not necessarily completely wash out aerosols and their precursors [Dawson et al., 2007]. Increases in precipitation in the west during JJA are generally small in magnitude $(<0.2 \mathrm{~mm} /$ day $)$ despite large percentage changes $(>50 \%)$. The decrease in precipitation over Texas and the increase in the Northeast during JJA are on the order of $30 \%$ and are statistically significant (at 5\%). Precipitation increases almost $50 \%$ in the southeast in SON and decreases approximately $40 \%$ in the northeast during that same time, but SON precipitation changes are generally not statistically significant (at 5\%). Models reviewed by IPCC [2007] generally predict increased precipitation over North America,

with a warming climate (A1B), except for the Southwest, with increases in the northeast and decreases in the southwest more certain. Regional projected precipitation changes have large uncertainty, indicated by the fact that about half of the 21 models in the work of IPCC predict increases in precipitation and about half predict decreases in precipitation across most of the U.S. for JJA.

[33] The boundary layer depth over the U.S. is predicted to generally decrease from the present day to 2050 (Figure 4). In contrast, there is a particularly strong increase in the afternoon PBL depth of about $30 \%$ over Texas during JJA associated with the northeastward movement of the Bermuda high and the associated drying and warming of Texas [Wu et al., 2008]. Increases and decreases in the PBL depth are generally less than $20 \%$. Note that decreases in the PBL depth (favoring higher aerosol concentrations) are generally associated with increases in precipitation (favoring lower aerosol concentrations), and these two changes will generally have opposite effects on aerosol concentrations.

[34] The DJF and SON seasons are predicted to experience particularly strong changes in the zonal winds in the lowest model level across the U.S. (Figure 5) with westerlies doubling in strength during SON. During DJF, the westerlies are predicted to decrease in strength, while during SON, both the westerlies and easterlies increase in strength. The increase in westerly wind strength in SON is consistent with the ensemble of models examined by IPCC [2007] that show a strengthening and northward shift in mid-latitude westerlies particularly in autumn and winter for 2100 under A1B projections (although the meteorology here shows a weakening of the westerlies in DJF in 2050). The DJF trend in zonal winds is consistent with trends using 10 years of present-day and future GISS meteorology although the decrease is only significant in the midwest (at 25\%). The SON trend of weakening easterlies in the south and strengthening westerlies in the north is reflected in trends using 10 years of GISS zonal winds at level 1 (at surface) and level 7 (at approximately $5 \mathrm{~km}$ ) and significant at the $25 \%$ level near the east coast. Additional changes in

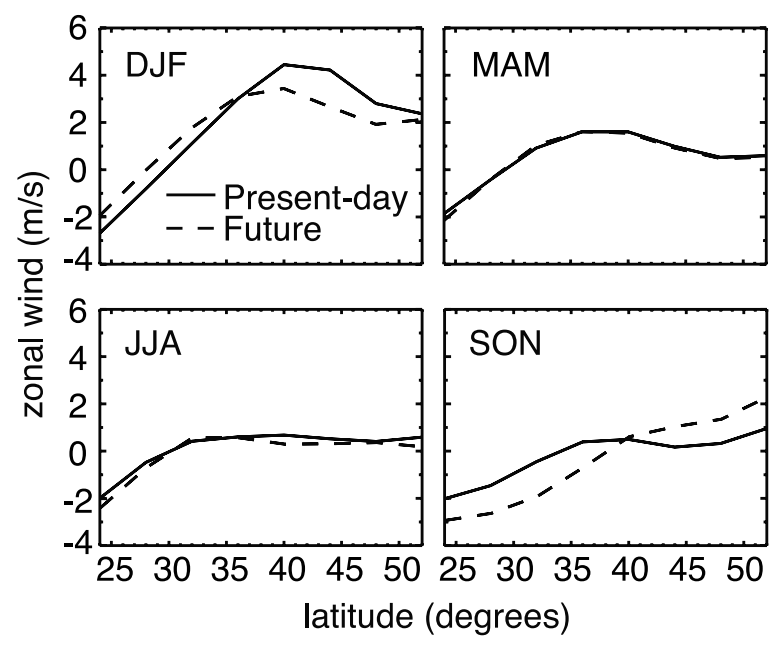

Figure 5. Predicted level 1 (approximately $0.13 \mathrm{~km}$ ) zonal wind for the present day (1999-2001) and future (20492051) over the U.S. (averaged from $120^{\circ}$ to $60^{\circ} \mathrm{W}$ longitude). 


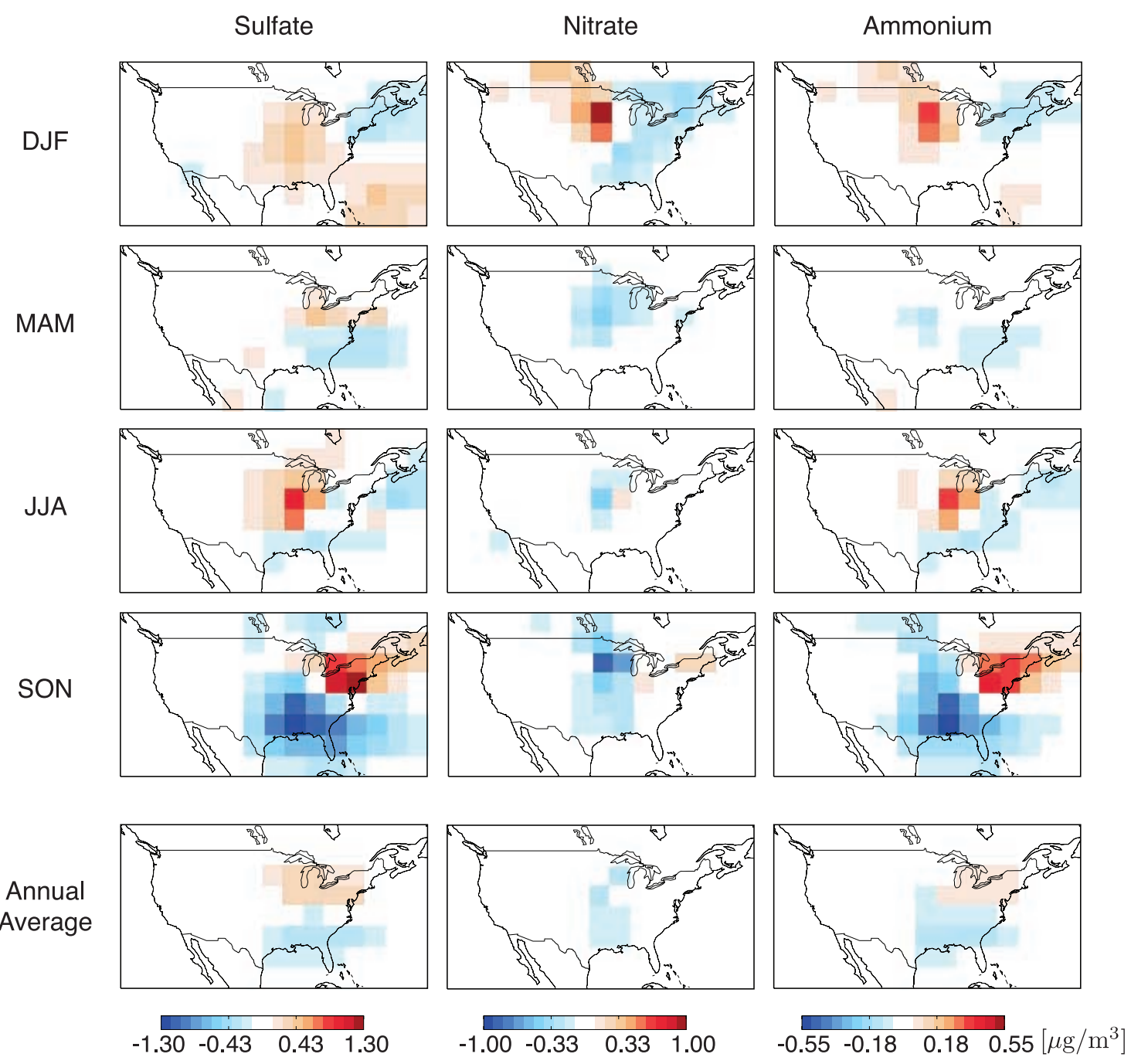

Figure 6. Predicted change in U.S. surface-level aerosol concentrations due to changes in climate alone from the present day (1999-2001) to the future (2049-2051). Greenhouse gases follow the IPCC scenario A1B. Anthropogenic emissions are held at present-day values, but natural emissions may change in response to climate.

meteorology will be discussed in relation to predicted changes in aerosol levels during each season.

[35] Figure 6 shows the predicted change in surface concentrations of inorganic aerosols from the present day to 2050 as a result of predicted changes in meteorology alone. Table 3 summarizes the climatic parameters important for explaining the changes in concentrations of sulfate, nitrate, and ammonium aerosols. Each season will be discussed in the following sections since different meteorological changes are influential during different times of the year.

\subsubsection{DJF Season}

[36] In winter, $\mathrm{SO}_{2}$, total nitrate, $\mathrm{SO}_{4}^{2-}$, and $\mathrm{NH}_{4}^{+}$are predicted to show similar trends between 2000 and 2050, with increased concentrations over the Midwest but decreased concentrations over the northeast U.S. (Figure 6). Changes in aerosol-phase nitrate are generally correlated with changes in total nitrate except for the southeast U.S., where changes reflect additional processes including the influence of higher temperatures. The largest change in nitrate for the southeast U.S. is predicted to occur in a present-day ammonia-limited regime according to the gas ratio $(<1)$, so increased sulfate levels may result in less ammonia being available for nitrate. Additional factors may be influential in the southeast such as decreased dry deposition as a result of weaker westerlies and changes in vertical transport. Future predicted changes in the planetary boundary layer (PBL) also play a role determining concentration changes in the Midwest and Southeast, since the boundary layer is generally lower leading to higher surface concentrations. Changes in precipitation and convective flux do not appear to contribute significantly to changes in DJF concentrations.

[37] Since many species, including carbon monoxide and black carbon, follow a trend similar to the inorganic aerosols, changes in transport must be a major determining factor for changes in concentrations. Predicted changes in the strength of the wintertime westerly winds and meridional winds across the United States are expected to play a major role in determining changes in inorganic aerosol concentrations. The westerly winds in the lower $2.5 \mathrm{~km}$ of the atmosphere decrease in strength over most of the U.S., 
Table 3. Implications of Changes in Meteorological Parameters From 2000 to 2050 for Inorganic Aerosol Concentrations Over the United States

\begin{tabular}{|c|c|c|}
\hline Season & Meteorological Parameter & Major Implications for Aerosols ${ }^{\mathrm{a}}$ \\
\hline \multirow[t]{5}{*}{ DJF } & Precipitation & Increased wet deposition of species over MW and $\mathrm{SE}^{\mathrm{b}}$ \\
\hline & Temperature & Nitrate decreases (noticeably in SE) as it partitions to nitric acid \\
\hline & Zonal wind & $\begin{array}{l}\text { Slower transport in MW leads to increased concentrations in MW; reduced transport } \\
\text { of aerosols and precursors to the NE }\end{array}$ \\
\hline & Meridional wind & Faster transport away from NE and concentrations decrease \\
\hline & PBL & Concentrations increase in MW and SE \\
\hline \multirow[t]{4}{*}{ MAM } & Precipitation & $\begin{array}{l}\text { Increased wet deposition of aerosols and/or soluble precursor gases and decreased } \\
\text { aerosol concentrations }\end{array}$ \\
\hline & Temperature & Nitrate decreases as it partitions to nitric acid, higher biogenic emissions influence $\mathrm{HO}_{x}$ \\
\hline & Humidity & Favors higher $\mathrm{HO}_{x}$ production, catalyzes $\mathrm{H}_{2} \mathrm{O}_{2}$ formation, and leads to more sulfate formation \\
\hline & PBL & Indicates reduced surface ventilation, but effect does not appear to be dominant \\
\hline \multirow[t]{6}{*}{ JJA } & Precipitation & Reduces concentrations along east coast \\
\hline & Temperature & Nitrate decreases as it partitions to nitric acid \\
\hline & Humidity & Leads to more sulfate formation \\
\hline & PBL & Concentrations in MW and NE increase due to reduced ventilation, sulfate decreases in SE \\
\hline & Cyclone frequency & More frequent stagnation [Wu et al., 2008] suspected to lead to increased concentrations in MW \\
\hline & Convective flux & Decreased ventilation favors increased concentrations; important for sulfate \\
\hline \multirow[t]{4}{*}{ SON } & Precipitation & Contributing factor for concentration decreases in the SE and increases in the NE \\
\hline & Temperature & Nitrate decreases as it partitions to gas phase \\
\hline & Zonal wind & Faster transport away from Midwest, aerosols and precursors transported to the NE \\
\hline & $\begin{array}{l}\text { Convective flux/Vertical } \\
\text { transport }\end{array}$ & Contributing factor for concentration decreases in the SE and increases in the NE \\
\hline
\end{tabular}

${ }^{\mathrm{a}}$ See Figure 6 for predicted changes in aerosol concentrations.

especially in the Midwest and Northeast where the wind strength decreases by as much at $70 \%$ at $0.9 \mathrm{~km}$ in altitude. A lower PBL and weaker westerlies imply slower transport of aerosols away from regions in the Midwest and higher inorganic concentrations. Weaker westerlies also reduce the transport of aerosols and their precursors to the Northeast. Increased precipitation in the Midwest may further reduce the amount of aerosols transported eastward. Present-day meridional winds generally flow south to north in the eastern U.S. during DJF. With climate change, the winds in the northeast U.S. are actually predicted to change direction and flow more intensely from north to south. As a result, aerosols and their precursors are transported more quickly away from the northeast U.S. and concentrations decrease.

\subsubsection{MAM Season}

[38] In spring, sulfate concentrations are predicted to increase in the Midwest and Northeast and decrease in the Southeast (Figure 6). Nitrate, total nitrate, and ammonium concentrations generally decrease. Increased wet deposition of gaseous $\mathrm{HNO}_{3}$ in addition to higher temperature causes decreased nitrate concentrations. Gas phase sulfate production generally decreases in the future as a result of lower $\mathrm{OH}$ concentrations due to climate change, but the increases in aqueous-phase oxidation are generally of larger magnitude than the changes in gas-phase production for the lowest 4 levels (approximately $1.5 \mathrm{~km}$ ) of the atmosphere. Although higher specific humidities are expected to increase $\mathrm{HO}_{x}$ $\left(\mathrm{HO}_{x}=\mathrm{OH}+\mathrm{HO}_{2}\right)$ production, higher temperatures and higher biogenic emissions can result in decreasing $\mathrm{OH}$ and increasing $\mathrm{HO}_{2}$ over the U.S. In the future springtime, $\mathrm{H}_{2} \mathrm{O}_{2}$ increases $20 \%$ to $40 \%$ because of higher temperatures and increased water vapor producing more $\mathrm{HO}_{x}$ (with perhaps a minor effect of water fostering the $\mathrm{HO}_{2}+\mathrm{HO}_{2}$ reaction). In the work of Liao et al. [2006], annually increased sulfate levels in the future in the eastern U.S. were attributed to higher oxidant concentrations.

\subsubsection{JJA Season}

[39] Predicted changes in concentrations during summer do not appear to be the result of a single dominant factor. Wu et al. [2008] examined changes in ozone concentrations during JJA with the same meteorology as used here. Ozone was predicted to increase in the Midwest and Northeast as a result of increased isoprene emissions, lower peroxyacetylnitrate stability, a more shallow PBL, reduced convective ventilation, and more frequent stagnation. Ozone in the Southeast was found to be insensitive to climate change as a result of the competing effects of isoprene emissions and meteorology. For aerosols, a lower PBL, reduced convective ventilation, and more frequent stagnation could lead to higher concentrations, and sulfate concentrations generally increase over the Midwest (Figure 6). Along the east coast and somewhat inland, higher $\mathrm{H}_{2} \mathrm{O}_{2}$ levels and a lower PBL are predicted to lead to more in-cloud $\mathrm{H}_{2} \mathrm{O}_{2}$ production of $\mathrm{SO}_{4}^{2-}$. More precipitation adjacent to the east coast acts to reduce sulfate. A deeper PBL over Texas and part of the Southeast contributes to sulfate and ammonium decreases in those regions. Changes in nitrate aerosol generally follow changes in total nitrate. Dry deposition of nitric acid can act as a positive feedback by reducing total nitrate when aerosol nitrate evaporates at higher temperatures [Aw and Kleeman, 2003].

\subsubsection{SON Season}

[40] Multiple species (total nitrate, $\mathrm{SO}_{4}^{2-}, \mathrm{SO}_{2}$, and $\mathrm{NH}_{4}^{+}$) show a similar trend during SON with decreasing concentrations in the southeast U.S. and increasing concentrations in the northeast U.S. (Figure 6). The increasing westerly zonal wind speed across the northern U.S. transports aerosols and their precursors away from the Midwest more quickly and transports nitrate to the Northeast where tem- 
(a)

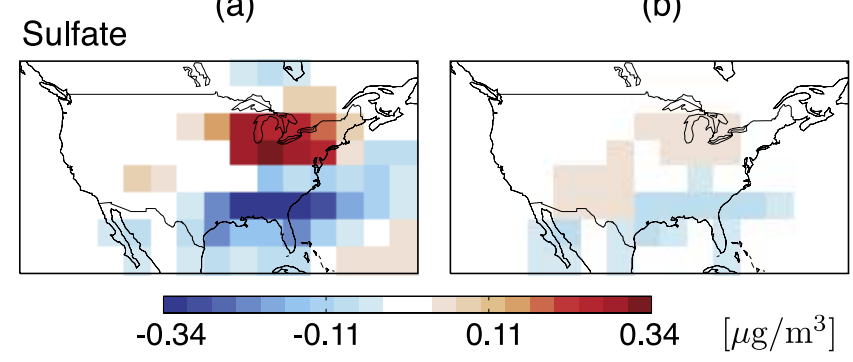

Nitrate

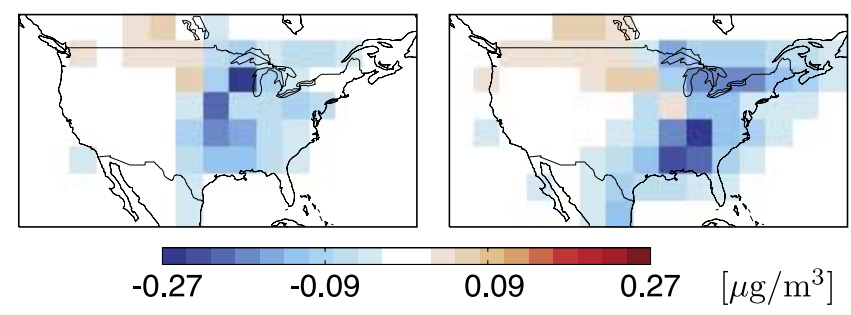

Ammonium

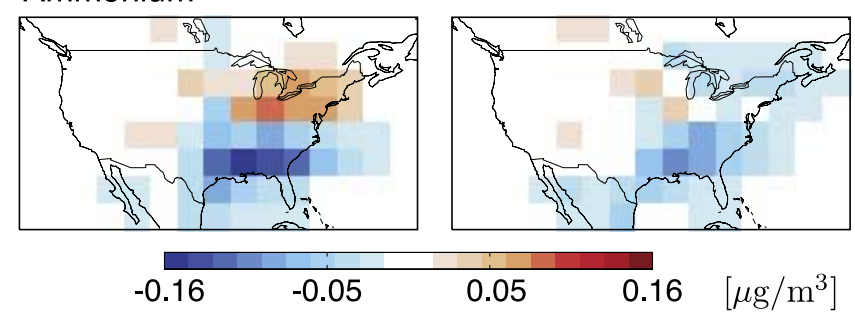

Sulfate-Nitrate-Ammonium Total

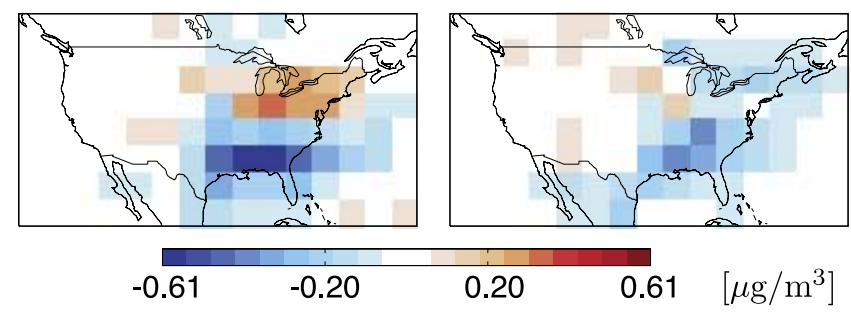

Figure 7. Predicted changes in aerosol concentrations due to climate change from the present day (1999-2001) to the future (2049-2051) with (a) present-day emissions and (b) future emissions (annually averaged). Column (a) is the same as the annual plots in Figure 6 except with a different scale. Column (a) represents the difference between simulations of future climate with present-day emissions and present-day climate with present-day emissions. Column (b) represents the difference between future climate with future anthropogenic emissions and present-day climate with future anthropogenic emissions.

perature increases are larger and sulfate increases are substantial. Thus, despite increases on the order of 0.4 to $1 \mathrm{ppb}$ (about 1 to $2.8 \mu \mathrm{g} / \mathrm{m}^{3}$ at standard temperature and pressure, STP) in total nitrate, aerosol nitrate shows relatively small increases in the Northeast. The Northeast may also see slightly less transport in the future during SON as meridional winds are predicted to decrease in strength in the Northeast and along the East Coast. In the northeast U.S., precipitation is predicted to decrease by as much as $40 \%$ and convective fluxes around $1.4 \mathrm{~km}$ in altitude decrease, both of which contribute to higher concentrations.
[41] For the southeast, changes in vertical transport and precipitation play a role in determining future inorganic aerosol concentrations. Precipitation is predicted to increase by as much as $50 \%$ in the southeast. Black carbon was used as a surrogate species to examine the effects of changes in precipitation. Hydrophobic black carbon concentrations generally increase in the southeast unlike hydrophilic black carbon which shows a pattern similar to sulfate. Thus increased wet removal must be the primary reason for decreases in the southeast during SON with changes in transport playing a minor role.

\subsubsection{Annual Changes}

[42] On an annual basis, sulfate concentrations are predicted to decrease over the Southeast and southern United States by up to $0.34 \mu \mathrm{g} / \mathrm{m}^{3}$, whereas sulfate increases over the Midwest and Northeast by up to $0.32 \mu \mathrm{g} / \mathrm{m}^{3}$. In the work of Tagaris et al. [2007], sulfate concentrations in 2050 for scenario A1B are generally predicted to increase in the U.S. because of climate change alone in the midwest, northeast, and southeast as a result of increases in climate sensitive $\mathrm{SO}_{2}$ emissions which increase by $4 \%$ in their study. The increases in sulfate concentration in the midwest and northeast $(>10 \%)$ were larger (relatively) than the changes in the southeast $(<1 \%)$ [Tagaris et al., 2007].

[43] Because of higher temperatures, future nitrate aerosol concentrations are expected to be lower, and on an annual basis, nitrate aerosol is predicted to decrease across almost the entire eastern U.S. with a maximum decrease of $0.24 \mu \mathrm{g} / \mathrm{m}^{3}$. Projected changes in nitrate aerosol are not purely a result of temperature increases, as total nitrate can increase or decrease in individual seasons (as discussed in the preceding sections). Higher absolute humidity can favor nitrate partitioning to the aerosol phase [Dawson et al., 2007], but this effect is not pronounced in the annual changes in this study.

[44] Ammonium changes reflect those of sulfate and nitrate. The largest annually averaged ammonium decrease of about $0.16 \mu \mathrm{g} / \mathrm{m}^{3}$ is predicted to occur over the South where both nitrate aerosol and sulfate decrease. Annual increases of ammonium do not exceed $0.09 \mu \mathrm{g} / \mathrm{m}^{3}$ over the midwest where sulfate increases.

[45] The annually averaged decrease in sulfate in the southeast U.S. (bottom row of Figure 6, first column of Figure 7) results from changes during SON. Racherla and Adams [2006] and Liao et al. [2006] found that sulfate concentrations near the surface over the eastern U.S. generally increase between the present day and future (2050 and 2100, scenario A2), consistent with the results shown here for the midwest and northeast. Racherla and Adams [2006] also predict that the largest seasonal decrease in sulfate burden between the present day and 2050 for the eastern U.S. will occur during SON as a result of increased precipitation. Predictions of regional changes in precipitation for the U.S. between the present day and future are not necessarily robust model results [IPCC, 2007], and studies may continue to give different predictions for changes in sulfate for the southeast unless projected precipitation changes are consistent in both magnitude and direction.

\subsection{Climate Penalty Versus Climate Benefit}

[46] As discussed in section 4.1, aerosol levels will change because of changes in climate alone. Wu et al. 

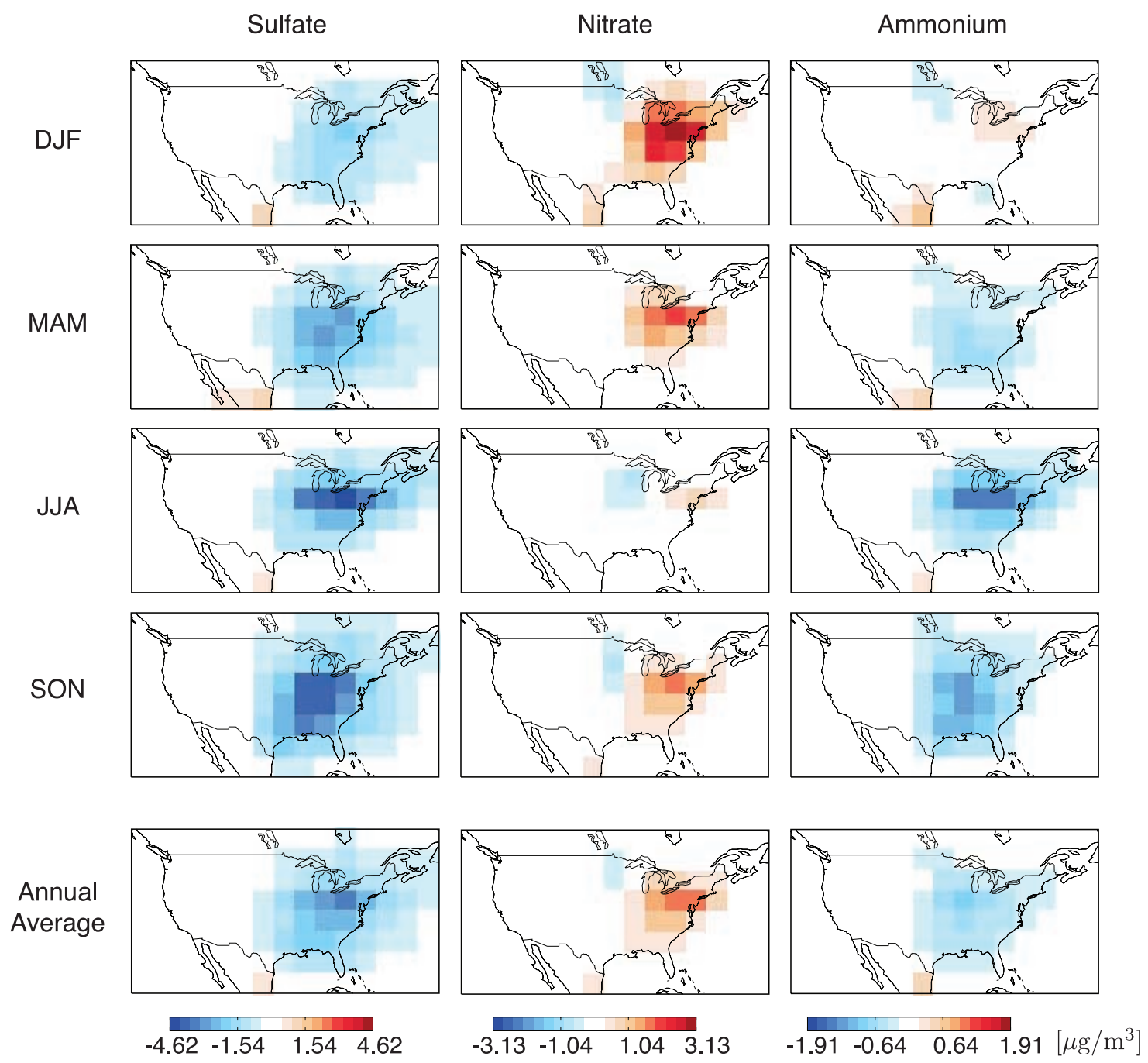

Figure 8. Predicted changes in U.S. surface-level aerosol concentrations from the present day (19992001) to the future (2049-2051) due to changes in anthropogenic emissions only (meteorology is held at present-day values). Emissions follow IPCC A1B scenario, as described in the text.

[2008] discussed the concept of a "climate change penalty" in which more aggressive emission controls may be necessary to meet ozone air quality goals in the future as a result of climate change. For sulfate-nitrate-ammonium aerosols, particulate air quality may benefit from climate change. In this section, the effect of climate change on aerosols is further explored with anthropogenic emissions at future levels. Figure 7 shows how alterations in climate alone are predicted to affect inorganic aerosol concentrations with either (a) present-day or (b) future anthropogenic emission levels. Both columns represent the effect of climate change, but anthropogenic emissions are held at either present-day (column (a)) or future (column (b)) levels. For present-day emissions, column (a), the annually-averaged change in ammonium closely resembles that of sulfate, and most ammonium would likely be in the form of ammonium sulfate. At future emission levels, column (b), the absolute changes in sulfate are predicted to be muted as concentrations of sulfate are generally predicted to be lower. The relative change in sulfate for most of the midwest and southeast with either present day or future anthropogenic emissions is on the order of $10 \%$ to $15 \%$. However, with future emissions, the sulfate change in the southwest becomes a larger relative amount at about $17 \%$. With future anthropogenic emissions ammonium changes more closely follow those of nitrate aerosol, and more ammonium is expected to be in the form of ammonium nitrate. With present-day emissions, nitrate decreases due to climate change are largest in the midwest where nitrate concentrations are generally highest with present-day emissions. However, with future emissions, the largest magnitude decreases occur in the southeast. Because of higher nitrate concentrations in the southeast using future anthropogenic emissions, changes in nitrate are still roughly $25 \%$ in the southeast near Texas for present-day or future emissions.

[47] With either set of emissions, the Southeast is predicted to experience decreases in inorganic aerosol levels as a result of the climate change scenario considered here. With present-day emissions and climate change, the Midwest and Northeast would experience degraded air quality. With future emissions, air quality improvements in the Southeast that would occur solely as a result of climate change are reduced, but air quality degradation in the Midwest and Northeast is also reduced. 
Sulfate
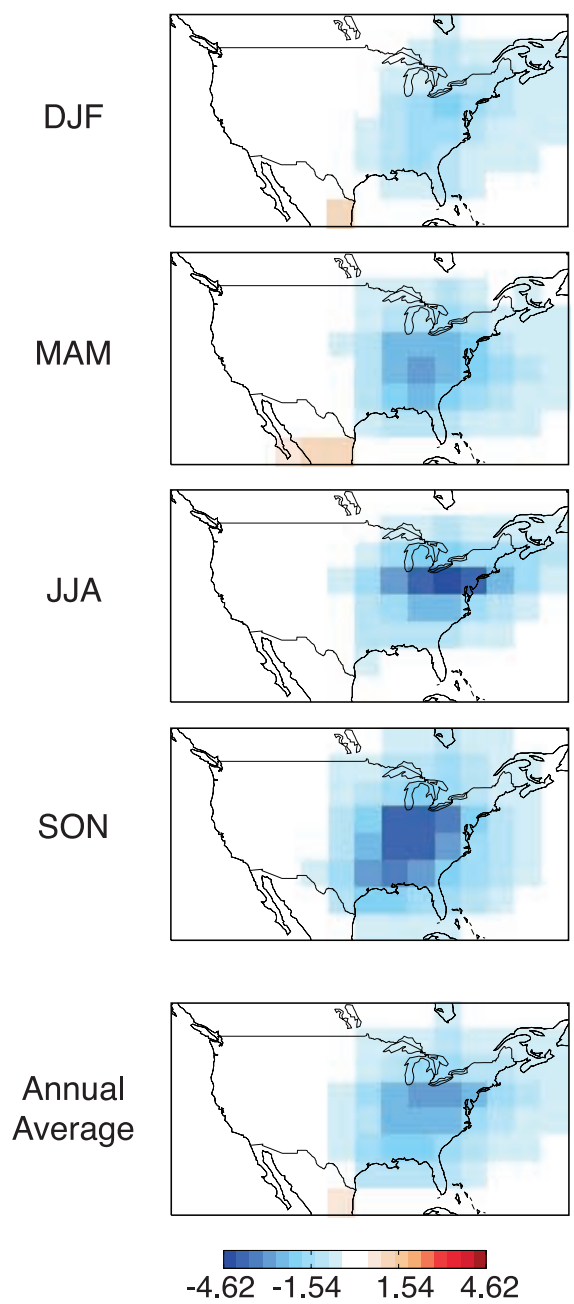

Nitrate
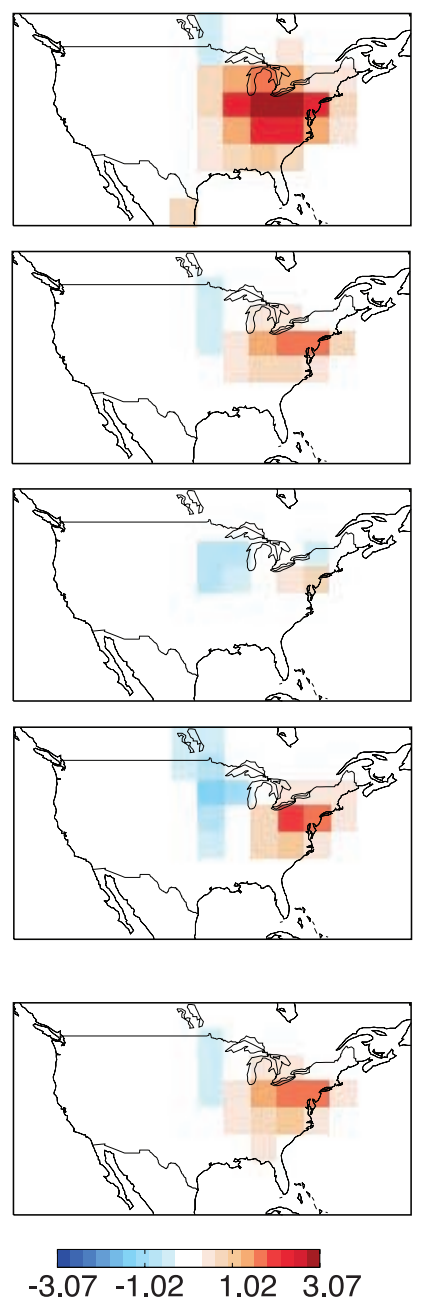

Ammonium
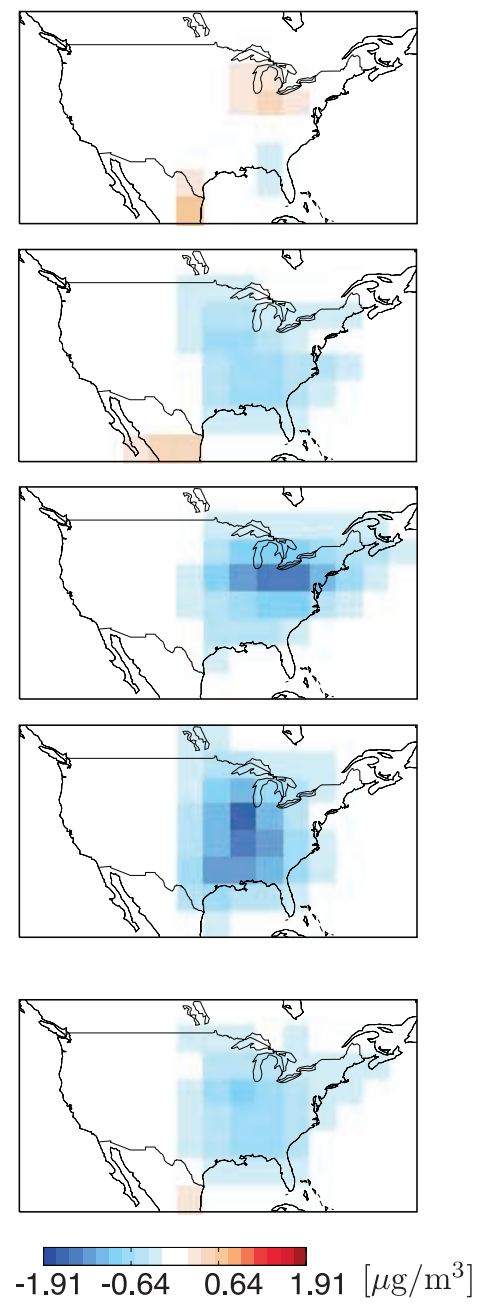

Figure 9. Predicted changes in U.S. surface-level aerosol concentrations due to changes in anthropogenic emissions and climate from the present day (1999-2001) to the future (2049-2051). Emissions follow IPCC A1B scenario, as described in text.

\subsection{Effect of Changes in Anthropogenic Emissions Alone}

[48] This section addresses the extent to which changes in anthropogenic emissions of aerosol precursors between the present day and 2050 would influence inorganic aerosol concentrations with present-day climate. Under the A1B scenario, anthropogenic $\mathrm{NO}_{x}$ emissions are predicted to increase $78 \%$ globally compared to the present day but decrease approximately $35 \%$ in the United States (Table 1). Ammonia emissions are predicted to increase globally and domestically by $32 \%$ and $40 \%$, respectively. $\mathrm{SO}_{2}$ emissions are predicted to increase $31 \%$ globally but decrease $74 \%$ in the United States.

[49] Sulfate concentrations in the U.S. are predicted to decrease in all seasons because of domestic reductions in $\mathrm{SO}_{2}$ emissions (Figure 8). The largest decreases are predicted to occur in JJA and SON. Annually-averaged sulfate concentrations are predicted to decrease by as much as $3.25 \mu \mathrm{g} / \mathrm{m}^{3}$ in the Northeast. In contrast, global $\mathrm{SO}_{2}$ emissions are projected to increase, which may have im- portant implications for background aerosol levels in the U.S. and the EPA Regional Haze Rule.

[50] Unlike sulfate, future nitrate aerosol concentrations are predicted to exhibit both increases and decreases (Figure 8). Lower domestic $\mathrm{NO}_{x}$ emissions lead to a general decrease of total nitrate in the United States. The largest reductions in total nitrate are predicted to occur in JJA, with decreases up to $1.43 \mathrm{ppb}$ (about $3.6 \mu \mathrm{g} / \mathrm{m}^{3}$ nitrate at STP). However, decreased sulfate levels coupled with increased ammonia emissions result in more ammonia available to react with nitrate. Total ammonia increases by as much as $1.9 \mathrm{ppb}$ (about $1.3 \mu \mathrm{g} / \mathrm{m}^{3} \mathrm{NH}_{3}$ at STP) in JJA. As a result of higher total ammonia and reduced sulfate, nitrate aerosol concentrations can more than double. In some locations, the gas ratio increases from $<1$ (indicating ammonia-limited) to values $>1$ (nitric acid-limited). Nitrate aerosol decreases in the Midwest occur where the gas ratio indicates a present day nitric acid-limited regime. Ammonium concentrations follow the trend in sulfate, except where ammonium reacts predominately with nitrate (DJF). In general, considering only emissions changes, U.S. levels of inorganic aerosols 
Table 4. Global Sulfate Budget

\begin{tabular}{lcccc}
\hline & $\begin{array}{c}\text { 2000 Climate } \\
\text { 2000 Emissions }\end{array}$ & $\begin{array}{c}\text { 2050 Climate } \\
\text { 2000 Emissions }\end{array}$ & $\begin{array}{c}\text { 2000 Climate } \\
\text { 2050 Emissions }\end{array}$ & $\begin{array}{c}\text { 2050 Climate } \\
\text { 2050 Emissions }\end{array}$ \\
\hline Burden (Tg S) & 0.28 & 0.28 & 0.39 & 0.40 \\
Emission (Tg S/yr) & 2.04 & 2.04 & 2.62 & 2.62 \\
Production (Tg S/yr) & & & & 14.92 \\
$\quad$ Gas phase & 8.24 & 8.15 & 14.74 & 23.17 \\
$\mathrm{H}_{2} \mathrm{O}_{2}$ in-cloud & 19.53 & 19.37 & 23.70 & 0.57 \\
$\mathrm{O}_{3}$ in-cloud & 1.54 & 1.52 & 0.63 & 0.16 \\
On fine sea salt & 0.16 & 0.16 & 0.16 & 37.31 \\
Deposition (Tg S/yr) & & & 37.91 & 4.14 \\
$\quad$ Wet & 28.72 & 28.35 & 3.95 & 3.5 \\
$\quad$ Dry & 2.80 & 2.89 & 3.4 & \\
Lifetime (days) & 3.2 & 3.3 & & \\
\hline
\end{tabular}

are predicted to be lower in the future than in the present day. An exception occurs in winter when an increase in the total sulfate-nitrate-ammonium inorganic aerosol concentration on the order of $1 \mu \mathrm{g} / \mathrm{m}^{3}$ is predicted in some locations.

\subsection{Effect of Changes in Both Climate and Anthropogenic Emissions}

[51] Predicted sulfate, nitrate, and ammonium concentration changes considering both future emissions and climate change (Figure 9) are similar to those due to emissions changes alone. For 2050 conditions, annual U.S. sulfate concentrations are predicted to decrease by up to $3.2 \mu \mathrm{g} / \mathrm{m}^{3}$, and ammonium decreases by up to $0.79 \mu \mathrm{g} / \mathrm{m}^{3}$. The percent decrease in sulfate, as high as $77 \%$, is similar to the percent decrease in $\mathrm{SO}_{2}$ emissions ( $74 \%$ in the U.S.). Ammonium decreases up to $61 \%$ in the southeast which is higher than the percent increase in ammonia emissions ( $40 \%$ in the U.S.).

[52] Nitrate increases in some areas by up to $1.67 \mu \mathrm{g} / \mathrm{m}^{3}$ and decreases in others by up to $0.43 \mu \mathrm{g} / \mathrm{m}^{3}$. Climate change slightly mitigates the effects of changes in anthropogenic emissions on nitrate levels.

[53] Bauer et al. [2007] predicted nitrate aerosol levels for 2030 under the A1B scenario. The emission projections used by Bauer et al. [2007] involve a decrease in $\mathrm{SO}_{2}$ and $\mathrm{NO}_{x}$, as in the present study. Changes in nitrate aerosol concentrations in the U.S. predicted in that study are somewhat similar to those presented here, with a decrease in the Midwest and an increase in the Northeast. The predictions differ in the southern U.S. where Bauer et al. [2007] predict a decrease in nitrate, whereas the present study predicts a slight increase.

\section{Global Budgets of Sulfate, Nitrate, and Ammonium}

\subsection{Present-Day Budgets}

[54] Table 4 shows the present-day global budget for sulfate aerosol. The present-day global burden of sulfate aerosol is predicted to be $0.28 \mathrm{Tg} \mathrm{S}$. This estimate is at the lower end of predicted present-day sulfate burdens, as summarized by Tsigaridis et al. [2006], and slightly outside the range of burdens reported in AeroCom Experiment A [Textor et al., 2006]. The effective wet deposition rate coefficient for this work is high compared to coefficients for the AeroCom models (but still within range), which contributes to the lower burden seen here. Differences in sulfate predictions can also result from different representations of precursor gas removal, chemical production, atmospheric transport, etc. [Textor et al., 2006]. The sulfate lifetime predicted here (against total deposition) is within the range of those from AeroCom Experiment A. Under present-day conditions in this work, the global sulfate source is $32 \mathrm{Tg} \mathrm{S} / \mathrm{yr}$. The largest contribution, about $62 \%$ globally and annually averaged, is in-cloud oxidation of $\mathrm{SO}_{2}$ by hydrogen peroxide $\left(\mathrm{H}_{2} \mathrm{O}_{2}\right)$. In-cloud oxidation by ozone contributes $5 \%$ of the global source, gas-phase $\mathrm{SO}_{2}$ oxidation is $26 \%$, and sulfate production on submicrometer sea salt is $1 \%$. Direct emission of sulfate aerosol represents $6 \%$ of global sulfate sources.

[55] Nitrate and ammonium production listed in Table 5 represents the net production from gas-aerosol equilibrium partitioning. Aerosol nitrate is predicted to have a presentday global burden of $0.35 \mathrm{Tg}$ and a lifetime of 7.6 days (against wet and dry deposition). The ammonium burden is $0.24 \mathrm{Tg}$ with a lifetime of 3.7 days. The predicted nitrate burden compares well with previous GEOS-Chem simulations using assimilated meteorology, but sulfate and ammonium burdens are slightly lower than those in the work of Park et al. [2004] as a result of a shorter lifetime against deposition. Wet deposition is the dominant loss process for sulfate, nitrate, and ammonium, with over $80 \%$ of each species lost through wet processes.

[56] The ammonium lifetime is shorter than that of nitrate since ammonium is associated with both sulfate and nitrate. Sulfate has a shorter lifetime than nitrate, which reflects the spatial distribution of its production in relation to removal

Table 5. Global Budgets of Nitrate and Ammonium Aerosol ${ }^{\mathrm{a}}$

\begin{tabular}{|c|c|c|c|c|c|c|c|c|}
\hline & \multicolumn{4}{|c|}{ Nitrate } & \multicolumn{4}{|c|}{ Ammonium } \\
\hline & $\begin{array}{l}2000 \mathrm{C} \\
2000 \mathrm{E}\end{array}$ & $\begin{array}{l}2050 \mathrm{C} \\
2000 \mathrm{E}\end{array}$ & $\begin{array}{l}2000 \mathrm{C} \\
2050 \mathrm{E}\end{array}$ & $\begin{array}{l}2050 \mathrm{C} \\
2050 \mathrm{E}\end{array}$ & $\begin{array}{l}2000 \mathrm{C} \\
2000 \mathrm{E}\end{array}$ & $\begin{array}{l}2050 \mathrm{C} \\
2000 \mathrm{E}\end{array}$ & $\begin{array}{l}2000 \mathrm{C} \\
2050 \mathrm{E}\end{array}$ & $\begin{array}{l}2050 \mathrm{C} \\
2050 \mathrm{E}\end{array}$ \\
\hline Burden $(\mathrm{Tg})$ & 0.35 & 0.27 & 0.44 & 0.35 & 0.24 & 0.23 & 0.37 & 0.36 \\
\hline Production (Tg/yr) & 16.8 & 15.1 & 28.0 & 24.8 & 24.3 & 23.1 & 37.0 & 35.4 \\
\hline Wet deposition (Tg/yr) & 13.7 & 12.2 & 23.1 & 20.3 & 21.1 & 19.9 & 32.2 & 30.5 \\
\hline Dry deposition ( $\mathrm{Tg} / \mathrm{yr})$ & 3.1 & 2.9 & 5.0 & 4.6 & 3.2 & 3.2 & 4.8 & 4.9 \\
\hline Lifetime (days) & 7.6 & 6.6 & 5.8 & 5.1 & 3.7 & 3.6 & 3.7 & 3.7 \\
\hline
\end{tabular}

${ }^{a}$ Budgets for present-day and future climate (2000C, 2050C) and present-day and future emissions (2000E, 2050E). 


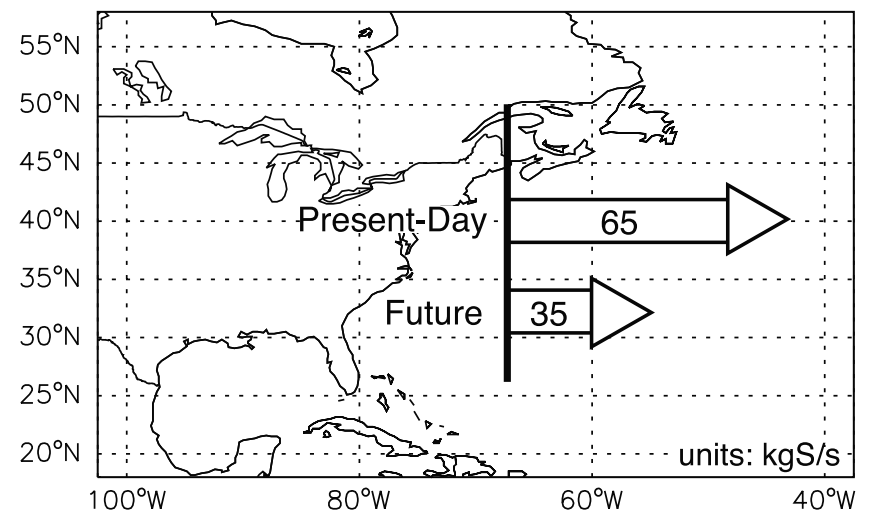

Figure 10. Annual change in $\mathrm{SO}_{x}\left(\mathrm{SO}_{2}+\mathrm{SO}_{4}^{2-}\right)$ outflow from the U.S. due to changes in climate and emissions from present day to 2050. Transport is calculated through a plane (shown) that runs along $67.5^{\circ} \mathrm{W}$ from $26^{\circ}$ to $50^{\circ} \mathrm{N}$. Numbers are averaged over the three present-day years or future years, as applicable.

by precipitation. Sulfate produced in-cloud is expected to have a much shorter lifetime than sulfate produced in the gas-phase [Koch et al., 2003]. Note that in GEOS-Chem, $\mathrm{SO}_{2}$ dissolved in precipitation is converted to $\mathrm{SO}_{4}^{2-}$ when evaporation of that precipitation occurs. This source is included in the wet deposition row in Table 4; thus wet deposition represents the net wet removal as a result of rainout, washout, and scavenging in convective updrafts.

\subsection{Effect of Changes in Climate Alone}

[57] Global burdens and budgets of sulfate, nitrate, and ammonium aerosol for future climate are presented in Tables 4 and 5. As in the study of Mahowald et al. [2006], the global sea salt source and burden are found to be relatively insensitive to climate change since sea salt emission and the global burden increase by less than $2 \%$. The sulfate budget also changes imperceptibly with climate. In the work of Liao et al. [2006], simulating equilibrium climate under the A2 scenario in 2100 produced larger changes than those in this study, presumably as a result of more pronounced changes in climate. Gas-phase production of sulfate decreased while in-cloud formation increased by $5 \%$ in the work of Liao et al. [2006]. Both Liao et al. [2006] and Racherla and Adams [2006] showed decreased sulfate burdens in the future due to climate change alone of $14 \%$ and $8 \%$ for 2100 and 2050 (A2 scenario), respectively.

[58] The nitrate aerosol burden is predicted to decrease by about $21 \%$ between the present-day and future climate. This decrease is most likely a consequence of higher temperatures and increased partitioning to the gas phase. The lifetime of nitrate aerosol is also predicted to decrease to 6.6 days because of changes in wet removal. The decrease in nitrate burden compares well with that of other models using the A2 scenario which predict decreases in nitrate due to climate change alone varying from $13 \%$ to $47 \%$ [Liao et al., 2006; Racherla and Adams, 2006]. Racherla and Adams [2006] attribute the decrease in burdens and lifetimes of many PM species to increased wet deposition in the future. Liao et al. [2006] found that more nitrate remains in the gas phase. In the present study, wet deposition of nitrate is predicted to decrease by about $11 \%$ in the future, and most of the future reduced nitrate burden results from less nitrate partitioning into the aerosol phase. However, increased precipitation in the future can play a role in reducing the lifetime of nitrate against deposition.

[59] Changes in nitrate will influence ammonium. The burden, wet deposition, and production of ammonium are predicted to decrease by $5 \%$ to $6 \%$ in this study. Changes in ammonium here are milder than those predicted by Racherla and Adams [2006] and likely reflect the fact that the sulfate burden is relatively insensitive to climate change under the A1B scenario. The slight decrease in ammonium production may reflect the reduced nitrate burden. Both studies (this one and that of Racherla and Adams [2006]) predict a decrease in the global ammonium burden in the future.

\subsection{Effect of Changes in Anthropogenic Emissions Alone}

[60] Sulfate, nitrate, and ammonium global burdens are predicted to change significantly in response to predicted changes in anthropogenic emissions (under present-day climate, Tables 4 and 5). The sulfate burden increases $39 \%$ to $0.39 \mathrm{Tg} \mathrm{S}$ as a result of higher global $\mathrm{SO}_{2}$ emissions. Gas-phase formation of $\mathrm{SO}_{4}^{2-}$ increases $79 \%$ and represents $35 \%$ of sulfate production (compared to $26 \%$ in the present day). Sulfate production by aqueous $\mathrm{H}_{2} \mathrm{O}_{2}$ reaction also increases by about $21 \%$, but $\mathrm{O}_{3}$ aqueous production decreases almost 59\%. Liao et al. [2006] also indicate that with future emissions, in-cloud production from reaction with $\mathrm{O}_{3}$ will decrease. Present-day in-cloud production by reaction with $\mathrm{O}_{3}$ is largest over North America and Europe and these regions are projected to have lower $\mathrm{SO}_{2}$ emissions in the future. Despite increases in both wet and dry deposition of sulfate, the sulfate lifetime increases slightly compared to the present day to 3.4 days. Globally, higher $\mathrm{NO}_{x}$ and ammonia emissions lead to the nitrate aerosol burden increasing $28 \%$ compared to the present day. Both nitrate production and wet deposition increase in magnitude, and the nitrate lifetime decreases from 7.6 to 5.8 days. The ammonium burden increases $53 \%$ to $0.37 \mathrm{Tg}$, but the ammonium lifetime remains relatively constant at 3.7 days. All source and loss processes increase in magnitude for ammonium and nitrate aerosol.

\subsection{Effect of Changes in Both Climate and Anthropogenic Emissions}

[61] Most studies show the future sulfate burden following the global change in $\mathrm{SO}_{2}$ emissions [Liao et al., 2006; Bauer et al., 2007; Shindell et al., 2007]. In contrast, for the B1 scenario in 2030, Unger et al. [2006] calculated an increased sulfate burden despite decreased global $\mathrm{SO}_{2}$ emissions; this effect was attributed to emissions shifting to subtropical regions with higher oxidation rates and lower wet deposition. The predicted sulfate burden change in the present study is larger for changes in both climate and emissions together than for either change alone (Table 4). Changes in the sulfate production and loss processes are dominated by the effects of changes in $\mathrm{SO}_{2}$ emissions alone, but the effects of climate change and emissions together on gas-phase production of sulfate are not additive. The sulfate lifetime increases slightly over the control case by 0.3 days.

[62] The aerosol nitrate burden is predicted to remain relatively constant at $0.35 \mathrm{Tg}$ considering combined 
Table 6. Annually Averaged and Wintertime Outflow in $\mathrm{kgS} / \mathrm{s}$ of $\mathrm{SO}_{x}$ From the Eastern U.S. (Location Depicted in Figure 10) for the Present Day (1999-2001) and Future (2049-2050) Considering Both Changes in Climate and Emissions ${ }^{\mathrm{a}}$

\begin{tabular}{lccc}
\hline & Present Day & Future & Percentage Change (\%) \\
\hline Annual $(\mathrm{kgS} / \mathrm{s})$ & & & \\
$\mathrm{SO}_{2}$ & 38 & 19 & -51 \\
$\mathrm{SO}_{4}^{2-}$ & 27 & 17 & -37 \\
$\mathrm{SO}_{x}$ & 65 & 35 & -45 \\
$\mathrm{DJF}(\mathrm{kgS} / \mathrm{s})$ & & & \\
$\mathrm{SO}_{2}$ & 78 & 33 & -58 \\
$\mathrm{SO}_{4}^{2-}$ & 36 & 26 & -29 \\
$\mathrm{SO}_{x}$ & 115 & 59 & -49 \\
\hline
\end{tabular}

${ }^{\text {a}}$ Right column: the percentage change between the present-day and future.

changes in climate and emissions (Table 5). However, the nitrate lifetime decreases significantly to 5.1 days. Formation increases due to higher precursor $\left(\mathrm{NO}_{x}\right.$ and $\left.\mathrm{NH}_{3}\right)$ emissions but decreases due to higher temperatures; the two effects effectively compensate for each other in terms of the global burden. For other scenarios or models, one effect may dominate over the other [Liao et al., 2006; Bauer et al., 2007]. Shindell et al. [2007] calculated that the nitrate burden (excluding nitrate on dust) was approximately the same in 2030 and 2050 but slightly lower than that in the present day under A1B despite increasing global $\mathrm{NO}_{x}$ and $\mathrm{NH}_{3}$ emissions. The assumed increase in $\mathrm{NH}_{3}$ emissions was much smaller in the work of Shindell et al. [2007] than in other studies [Adams et al., 2001; Liao and Seinfeld, 2005; Liao et al., 2006; Bauer et al., 2007]. Bauer et al. [2007] (A1B 2030) determined that future nitrate depends most strongly on changes in ammonia emissions between the present and 2030. Studies that consider only emissions changes and not the effects of climate change on future nitrate levels show a quadrupling of the nitrate global burden in 2100 under the A2 scenario [Adams et al., 2001; Liao and Seinfeld, 2005]. The current study highlights the need to consider the effect of climate change when predicting future aerosol levels.

[63] For ammonium, the global burden increase under both climate and emission changes is primarily due to increased anthropogenic $\mathrm{NH}_{3}$ emissions with some dampening from climate change. The lifetime of ammonium is predicted to remain relatively constant because of an increased burden and an increased rate of production.

\section{Implications for Eastern U.S. Outflow}

[64] In this section, the effect of changes in climate and emissions on sulfur outflow from the U.S. east coast are examined. $\mathrm{SO}_{2}$ and $\mathrm{SO}_{4}^{2-}$ in U.S. outflow were chosen for further examination since pollution transport has been shown to affect sulfate concentrations over the Atlantic Ocean and on different continents [Park et al., 2004; Benkovitz et al., 2006; Heald et al., 2006; Chin et al., 2007; Koch et al., 2007; Liu et al., 2008]. The effect of long-range transport on nitrate concentrations [Park et al., 2004 ] is less well known. To quantify the outflow of sulfur from the U.S., the rate of transport of sulfur is obtained at $67.5^{\circ} \mathrm{W}$ from $26^{\circ}$ to $50^{\circ} \mathrm{N}$ (Figure 10 ). Note that some pollution from Canada will also be included in this outflow. For the present-day simulations performed here, the largest seasonal $\mathrm{SO}_{x}\left(\mathrm{SO}_{x}=\mathrm{SO}_{2}+\mathrm{SO}_{4}^{2-}\right)$ outflow rate across this plane occurs during DJF followed by MAM. Exported $\mathrm{SO}_{x}$ tends to have significant contributions of $\mathrm{SO}_{4}^{2-}$ and $\mathrm{SO}_{2}$ although $\mathrm{SO}_{2}$ usually dominates in winter and $\mathrm{SO}_{4}^{2-}$ can dominate in summer reflecting the shift in photochemistry and $\mathrm{SO}_{4}^{2-}$ production in the U.S. DJF also experiences particularly strong westerlies (Figure 5), which can lead to higher rates of export than in other seasons.

[65] Table 6 shows the annually averaged and DJF seasonal transport rates of $\mathrm{SO}_{2}, \mathrm{SO}_{4}^{2-}$, and $\mathrm{SO}_{x}$ across $67.5^{\circ} \mathrm{W}$ from $26^{\circ}$ to $50^{\circ} \mathrm{N}$ for the present day and future. The table also shows how the transport is predicted to change in the future because of changes in climate and emissions combined. Outflow of $\mathrm{SO}_{2}$ and $\mathrm{SO}_{4}^{2-}$ decreases in the future annually as well as during DJF as a result of lower $\mathrm{SO}_{2}$ emissions and weaker DJF westerlies. The changes in $\mathrm{SO}_{x}$ outflow are substantial; export is reduced $45 \%$ on an annual basis and $49 \%$ during DJF.

\section{Conclusions}

[66] Changes in both climate and emissions will influence future inorganic aerosol (sulfate, nitrate, and ammonium) concentrations. The atmospheric chemical transport model, GEOS-Chem, driven by meteorology from the GISS GCM, allows for the separation of the effects of changes in climate from those in emissions. The GEOS-Chem/GISS framework with the inorganic gas-aerosol equilibrium model, ISORROPIA II, generally provides a good representation of present-day sulfate, nitrate, and ammonium levels in the United States; an exception is the under-prediction of nitrate in the western United States. Ammonia inventories represent a significant source of uncertainty for nitrate aerosol predictions, but sensitivity tests indicate that changes to the $\mathrm{NH}_{3}$ inventory alone will likely not correct nitrate estimates in the West.

[67] Future changes in meteorological parameters such as precipitation are somewhat uncertain. This work is intended to give an indication of how sulfate, nitrate, and ammonium aerosols may respond to future climate for the A1B scenario in 2050 and some meteorological changes that may be important for aerosols in this, and other scenarios. Climate change alone is predicted to impact aerosol concentrations with different climatic changes being important in different seasons. In some seasons, like winter, many different species show a similar pattern and one meteorological change appears to dominate changes in aerosol concentrations, whereas in other seasons, like summer, a single controlling factor cannot be isolated. Although aerosols are particularly sensitive to changes in precipitation, changes in precipitation are not always the governing factor for changes in concentrations.

[68] Simulations based on projected future emissions indicate that higher PM levels may occur in winter (DJF) because of increased nitrate aerosol, but domestic $\mathrm{SO}_{2}$ emission reductions will have benefits in all seasons. This study highlights the important role of ammonia emissions in determining inorganic aerosol levels. Allowing ammonia to increase while reducing sulfate partially negates some advantages of $\mathrm{SO}_{2}$ controls.

[69] Studies summarized by IPCC [2007] indicate that extreme meteorological events can be expected to become 
more prevalent in the future. Although the study here focuses on seasonally and annually averaged concentrations, the effects of climate change on short-term, high-concentration events merits examination. High-concentration events may show trends different from those examined here as they are likely to reflect changes in episodic events. In addition, under the emission scenario considered here (A1B) domestic emissions of $\mathrm{NO}_{x}$ and $\mathrm{SO}_{2}$ are predicted to decrease while global emissions increase. The result of domestic $\mathrm{SO}_{2}$ emissions reductions will have benefits for the North Atlantic and other regions that receive U.S. pollution outflow. The implications of climate and emissions changes on intercontinental transport should be further examined.

[70] Acknowledgments. This work was supported by the U.S. Environmental Protection Agency's STAR Program (grants RD830959 and RD833370). Havala Pye was supported by a National Science Foundation Graduate Research Fellowship. Hong Liao acknowledges the support from National Natural Science Foundation of China (grant 40775083). We would like to acknowledge the Clean Air Status and Trends Network (CASTNET) Discussions with Becky Alexander, Athanasios Nenes, Yang Zhang, and Donald Dabdub are greatly appreciated.

\section{References}

Adams, P. J., J. H. Seinfeld, D. Koch, L. Mickley, and D. Jacob (2001), General circulation model assessment of direct radiative forcing by the sulfate-nitrate-ammonium-water inorganic aerosol system, J. Geophys. Res., 106(D1), 1097-1111.

Alexander, B., R. J. Park, D. J. Jacob, Q. B. Li, R. M. Yantosca, J. Savarino, C. C. W. Lee, and M. H. Thiemens (2005), Sulfate formation in sea-salt aerosols: Constraints from oxygen isotopes, J. Geophys. Res., 110, D10307, doi:10.1029/2004JD005659.

Ames, R. B., and W. C. Malm (2001), Comparison of sulfate and nitrate particle mass concentrations measured by IMPROVE and the CDN, Atmos. Environ., 35(5), 905-916, doi:10.1016/S1352-2310(00)00369-1.

Ansari, A. S., and S. N. Pandis (1998), Response of inorganic PM to precursor concentrations, Environ. Sci. Technol., 32(18), 2706-2714.

Ansari, A. S., and S. N. Pandis (2000), Water absorption by secondary organic aerosol and its effect an inorganic aerosol behavior, Environ. Sci. Technol., 34(1), 71-77.

Aw, J., and M. J. Kleeman (2003), Evaluating the first-order effect of intraannual temperature variability on urban air pollution, J. Geophys. Res., 108(D12), 4365, doi:10.1029/2002JD002688.

Bauer, S. E., D. Koch, N. Unger, S. M. Metzger, D. T. Shindell, and D. G. Streets (2007), Nitrate aerosols today and in 2030: A global simulation including aerosols and tropospheric ozone, Atmos. Chem. Phys., 7(19), $5043-5059$.

Benkovitz, C. M., S. E. Schwartz, M. P. Jensen, and M. A. Miller (2006), Attribution of modeled atmospheric sulfate and $\mathrm{SO}_{2}$ in the Northern Hemisphere for June-July 1997, Atmos. Chem. Phys., 6, 4723-4738.

Bey, I., D. J. Jacob, R. M. Yantosca, J. A. Logan, B. D. Field, A. M. Fiore, Q. B. Li, H. G. Y. Liu, L. J. Mickley, and M. G. Schultz (2001), Global modeling of tropospheric chemistry with assimilated meteorology: Model description and evaluation, J. Geophys. Res., 106(D19), 23,073-23,095.

Bouwman, A. F., D. S. Lee, W. A. H. Asman, F. J. Dentener, K. W. VanderHoek, and J. G. J. Olivier (1997), A global high-resolution emission inventory for ammonia, Global Biogeochem. Cycles, 11(4), $561-587$

Chin, M., T. Diehl, P. Ginoux, and W. Malm (2007), Intercontinental transport of pollution and dust aerosols: Implications for regional air quality, Atmos. Chem. Phys., 7(21), 5501-5517.

Chung, S. H., and J. H. Seinfeld (2002), Global distribution and climate forcing of carbonaceous aerosols, J. Geophys. Res., 107(D19), 4407, doi:10.1029/2001JD001397.

Corbett, J. J., P. S. Fischbeck, and S. N. Pandis (1999), Global nitrogen and sulfur inventories for oceangoing ships, J. Geophys. Res., 104(D3), $3457-3470$

Dawson, J. P., P. J. Adams, and S. N. Pandis (2007), Sensitivity of $\mathrm{PM}_{2.5}$ to climate in the eastern U.S.: A modeling case study, Atmos. Chem. Phys., 7(16), 4295-4309.

de Gouw, J. A., et al. (2005), Budget of organic carbon in a polluted atmosphere: Results from the New England Air Quality Study in 2002, J. Geophys. Res., 110, D16305, doi:10.1029/2004JD005623.

de Gouw, J. A., et al. (2008), Sources of particulate matter in the northeastern United States in summer: 1. Direct emissions and secondary formation of organic matter in urban plumes, J. Geophys. Res., 113, D08301, doi:10.1029/2007JD009243.

Dockery, C., A. Pope, X. Xu, J. D. Spengler, J. H. Ware, M. E. Fay, B. G. Ferris, and F. E. Speizer (1993), An association between air pollution and mortality in six U.S. cities, N. Engl. J. Med., 329(24), 1753-1759.

Evans, M. J., and D. J. Jacob (2005), Impact of new laboratory studies of $\mathrm{N}_{2} \mathrm{O}_{5}$ hydrolysis on global model budgets of tropospheric nitrogen oxides, ozone, and OH, Geophys. Res. Lett., 32, L09813, doi:10.1029/ 2005 GL022469.

Fountoukis, C., and A. Nenes (2007), ISORROPIA II: A computationally efficient thermodynamic equilibrium model for $\mathrm{K}^{+}-\mathrm{Ca}^{2+}-\mathrm{Mg}^{2+}-\mathrm{NH}_{4}^{+}-\mathrm{Na}^{+}-$ $\mathrm{SO}_{4}^{2-}-\mathrm{NO}_{3}^{-}-\mathrm{Cl}^{-}-\mathrm{H}_{2} \mathrm{O}$ aerosols, Atmos. Chem. Phys., 7(17), 4639-4659.

Gilliland, A. B., R. L. Dennis, S. J. Roselle, and T. E. Pierce (2003), Seasonal $\mathrm{NH}_{3}$ emission estimates for the eastern United States based on ammonium wet concentrations and an inverse modeling method, J. Geophys. Res., 108(D15), 4477, doi:10.1029/2002JD003063.

Gilliland, A. B., K. W. Appel, R. W. Pinder, and R. L. Dennis (2006), Seasonal $\mathrm{NH}_{3}$ emissions for the continental United States: Inverse model estimation and evaluation, Atmos. Environ., 40(26), 4986-4998, doi:10.1016/J.ATMOSENV.2005.12.066.

Guenther, A., et al. (1995), A global-model of natural volatile organiccompound emissions, J. Geophys. Res., 100(D5), 8873-8892.

Heald, C. L., D. J. Jacob, R. J. Park, L. M. Russell, B. J. Huebert, J. H. Seinfeld, H. Liao, and R. J. Weber (2005), A large organic aerosol source in the free troposphere missing from current models, Geophys. Res. Lett., 32, L18809, doi:10.1029/2005GL023831.

Heald, C. L., D. J. Jacob, R. J. Park, B. Alexander, T. D. Fairlie, R. M. Yantosca, and D. A. Chu (2006), Transpacific transport of Asian anthropogenic aerosols and its impact on surface air quality in the United States, J. Geophys. Res., 111, D14310, doi:10.1029/2005JD006847.

Held, I. M., and B. J. Soden (2000), Water vapor feedback and global warming, Annu. Rev. Energy Environ., 25, 441-475, doi:10.1146/ ANNUREV.ENERGY.25.1.441

Henze, D. K., and J. H. Seinfeld (2006), Global secondary organic aerosol from isoprene oxidation, Geophys. Res. Lett., 33, L09812, doi:10.1029/ 2006GL025976.

Henze, D. K., J. H. Seinfeld, N. L. Ng, J. H. Kroll, T. M. Fu, D. J. Jacob, and C. L. Heald (2008a), Global modeling of secondary organic aerosol formation from aromatic hydrocarbons: High- vs. low-yield pathways, Atmos. Chem. Phys., 8(9), 2405-2420.

Henze, D. K., J. H. Seinfeld, and D. Shindell (2008b), Inverse modeling and mapping US air quality influences of inorganic $\mathrm{PM}_{2.5}$ precursor emissions using the adjoint of GEOS-Chem, Atmos. Chem. Phys. Discuss., 8(4), 15,031-15,099.

Intergovernmental Panel on Climate Change (IPCC) (2007), Climate Change 2007: The Physical Science Basis, Cambridge Univ. Press, Cambridge, U.K.

Jacob, D. J. (2000), Heterogeneous chemistry and tropospheric ozone, Atmos. Environ., 34(12-14), 2131-2159, doi:10.1016/S1352-2310(99)00462-8.

Jacob, D. J., and D. A. Winner (2009), Effect of climate change on air quality, Atmos. Environ., 43(1), 51-63, doi:10.1016/j.ATMOSENV.2008.09.051.

Jacob, D. J., B. D. Field, E. M. Jin, I. Bey, Q. B. Li, J. A. Logan, R. M. Yantosca, and H. B. Singh (2002), Atmospheric budget of acetone, J. Geophys. Res., 107(D10), 4100, doi:10.1029/2001JD000694.

Karydis, V. A., A. P. Tsimpidi, and S. N. Pandis (2007), Evaluation of a three-dimensional chemical transport model (PMCAMx) in the eastern United States for all four seasons, J. Geophys. Res., 112, D14211, doi:10.1029/2006JD007890.

Kleeman, M. J., and G. R. Cass (2001), A 3D Eulerian source-oriented model for an externally mixed aerosol, Environ. Sci. Technol., 35(24), 4834-4848, doi:10.1021/ES010996m.

Koch, D., J. Park, and A. Del Genio (2003), Clouds and sulfate are anticorrelated: A new diagnostic for global sulfur models, J. Geophys. Res., 108(D24), 4781, doi:10.1029/2003JD003621.

Koch, D., T. C. Bond, D. Streets, N. Unger, and G. R. van der Werf (2007), Global impacts of aerosols from particular source regions and sectors, J. Geophys. Res., 112, D02205, doi:10.1029/2005JD007024.

Leung, L. R., and W. I. Gustafson (2005), Potential regional climate change and implications to U.S. air quality, Geophys. Res. Lett., 32, L16711, doi:10.1029/2005GL022911.

Levy, H., M. D. Schwarzkopf, L. Horowitz, V. Ramaswamy, and K. L. Findell (2008), Strong sensitivity of late 21st century climate to projected changes in short-lived air pollutants, J. Geophys. Res., 113, D06102, doi: 10.1029/2007JD009176.

Liao, H., and J. H. Seinfeld (2005), Global impacts of gas-phase chemistryaerosol interactions on direct radiative forcing by anthropogenic aerosols and ozone, J. Geophys. Res., 110, D18208, doi:10.1029/2005JD005907.

Liao, H., W. T. Chen, and J. H. Seinfeld (2006), Role of climate change in global predictions of future tropospheric ozone and aerosols, J. Geophys. Res., 111, D12304, doi:10.1029/2005JD006852. 
Liao, H., D. K. Henze, J. H. Seinfeld, S. L. Wu, and L. J. Mickley (2007), Biogenic secondary organic aerosol over the United States: Comparison of climatological simulations with observations, J. Geophys. Res., 112, D06201, doi:10.1029/2006JD007813.

Liu, J., D. L. Mauzerall, and L. W. Horowitz (2008), Source-Receptor relationships between East Asian sulfur dioxide emissions and Northern Hemisphere sulfate concentrations, Atmos. Chem. Phys., 8(14), $3721-3733$

Mahowald, N. M., J. F. Lamarque, X. X. Tie, and E. Wolff (2006), Sea-salt aerosol response to climate change: Last Glacial Maximum, preindustrial, and doubled carbon dioxide climates, J. Geophys. Res., 111, D05303, doi:10.1029/2005JD006459.

Martin, R. V., D. J. Jacob, R. M. Yantosca, M. Chin, and P. Ginoux (2003), Global and regional decreases in tropospheric oxidants from photochemical effects of aerosols, J. Geophys. Res., 108(D3), 4097, doi:10.1029/ 2002JD002622.

Mendoza-Dominguez, A., and A. G. Russell (2001), Emission strength validation using four-dimensional data assimilation: Application to primary aerosol and precursors to ozone and secondary aerosol, J. Air Waste Manage. Assoc., 51(11), 1538-1550.

Meng, Z. Y., and J. H. Seinfeld (1996), Time scales to achieve atmospheric gas-aerosol equilibrium for volatile species, Atmos. Environ., 30(16), 2889-2900, doi:10.1016/1352-2310(95)00493-9.

Mhyre, G., A. Grini, and S. Metzger (2006), Modelling of nitrate and ammonium-containing aerosols in presence of sea salt, Atmos. Chem. Phys., 6(12), 4809-4821.

Mickley, L. J., D. J. Jacob, B. D. Field, and D. Rind (2004), Effects of future climate change on regional air pollution episodes in the United States, Geophys. Res. Lett., 31, L24103, doi:10.1029/2004GL021216.

Monahan, E. C., D. E. Spiel, and K. L. Davidson (1986), A model of marine aerosol generation via whitecaps and wave disruption, in Oceanic Whitecaps and Their Role in Air-Sea Exchange Processes, edited by E. C. Monahan and G. M. Niocaill, pp. 167-174, Springer, Norwall, Mass.

Morris, R., B. Koo, and G. Yarwood (2005), Evaluation of multisectional and two-section particulate matter photochemical grid models in the western United States, J. Air Waste Manage. Assoc., 55(11), 1683-1693.

Nakicenovic, N., and R. Swart (2000), Special Report on Emissions Scenarios, Cambridge Univ. Press, Cambridge, U.K.

Nightingale, P. D., P. S. Liss, and P. Schlosser (2000), Measurements of airsea gas transfer during an open ocean algal bloom, Geophys. Res. Lett., 27(14), 2117-2120.

Park, R. J., D. J. Jacob, B. D. Field, R. M. Yantosca, and M. Chin (2004), Natural and transboundary pollution influences on sulfate-nitrate-ammonium aerosols in the United States: Implications for policy, J. Geophys. Res., 109, D15204, doi:10.1029/2003JD004473.

Park, R. J., D. J. Jacob, N. Kumar, and R. M. Yantosca (2006), Regional visibility statistics in the United States: Natural and transboundary pollution influences, and implications for the Regional Haze Rule, Atmos. Environ., 40(28), 5405-5423, doi:10.1016/J.ATMOSENV.2006.04.059.

Pickering, K. E., Y. Wang, W.-K. Tao, C. Price, and J. F. Muller (1998), Vertical distributions of lightning $\mathrm{NO}_{x}$ for use in regional and global chemical transport models, J. Geophys. Res., 103(D23), 31,203-31,216.

Pinder, R. W., P. J. Adams, S. N. Pandis, and A. B. Gilliland (2006), Temporally resolved ammonia emission inventories: Current estimates, evaluation tools, and measurement needs, J. Geophys. Res., 111, D16310, doi:10.1029/2005JD006603.

Price, C., and D. Rind (1992), A simple lightning parameterization for calculating global lightning distributions, J. Geophys. Res., 97(D9), 9919-9933.

Racherla, P. N., and P. J. Adams (2006), Sensitivity of global tropospheric ozone and fine particulate matter concentrations to climate change, J. Geophys. Res., 111, D24103, doi:10.1029/2005JD006939.

Rae, J. G. L., C. E. Johnson, N. Bellouin, O. Boucher, J. M. Haywood, and A. Jones (2007), Sensitivity of global sulphate aerosol production to changes in oxidant concentrations and climate, J. Geophys. Res., 112, D10312, doi:10.1029/2006JD007826.

Rind, D., J. Lerner, J. Jonas, and C. McLinden (2007), Effects of resolution and model physics on tracer transports in the NASA Goddard Institute for Space Studies general circulation models, J. Geophys. Res., 112, D09315, doi:10.1029/2006JD007476.

Saltzman, E. S., D. B. King, K. Holmen, and C. Leck (1993), Experimentaldetermination of the diffusion-coefficient of dimethylsulfide in water, J. Geophys. Res., 98(C9), 16,481-16,486.

Schmidt, G. A., et al. (2006), Present-day atmospheric simulations using GISS ModelE: Comparison to in situ, satellite, and reanalysis data, J. Clim., 19(2), 153-192.
Seinfeld, J. H., and S. N. Pandis (2006), Atmospheric Chemistry and Physics: From Air Pollution to Climate Change, 2nd ed., John Wiley, New York.

Shindell, D. T., G. Faluvegi, S. E. Bauer, D. M. Koch, N. Unger, S. Menon, R. L. Miller, G. A. Schmidt, and D. G. Streets (2007), Climate response to projected changes in short-lived species under an A1B scenario from 2000-2050 in the GISS climate model, J. Geophys. Res., 112, D20103, doi:10.1029/2007JD008753.

Streets, D. G., T. C. Bond, T. Lee, and C. Jang (2004), On the future of carbonaceous aerosol emissions, J. Geophys. Res., 109, D24212, doi:10.1029/2004JD004902.

Tagaris, E., K. Manomaiphiboon, K. J. Liao, L. R. Leung, J. H. Woo, S. He, P. Amar, and A. G. Russell (2007), Impacts of global climate change and emissions on regional ozone and fine particulate matter concentrations over the United States, J. Geophys. Res., 112, D14312, doi:10.1029/ 2006JD008262.

Textor, C., et al. (2006), Analysis and quantification of the diversities of aerosol life cycles within AeroCom, Atmos. Chem. Phys., 6, 1777-1813.

Tsigaridis, K., M. Krol, F. J. Dentener, Y. Balkanski, J. Lathiere, S. Metzger, D. A. Hauglustaine, and M. Kanakidou (2006), Change in global aerosol composition since preindustrial times, Atmos. Chem. Phys., 6, 5143-5162.

Unger, N., D. T. Shindell, D. M. Koch, M. Amann, J. Cofala, and D. G. Streets (2006), Influences of man-made emissions and climate changes on tropospheric ozone, methane, and sulfate at 2030 from a broad range of possible futures, J. Geophys. Res., 111, D12313, doi:10.1029/ 2005JD006518.

Volkamer, R., J. L. Jimenez, F. San Martini, K. Dzepina, Q. Zhang, D. Salcedo, L. T. Molina, D. R. Worsnop, and M. J. Molina (2006), Secondary organic aerosol formation from anthropogenic air pollution: Rapid and higher than expected, Geophys. Res. Lett., 33, L17811, doi:10.1029/2006GL026899.

Wang, Y. H., D. J. Jacob, and J. A. Logan (1998), Global simulation of tropospheric $\mathrm{O}_{3}-\mathrm{NO}_{x}$-hydrocarbon chemistry. 1: Model formulation, J. Geophys. Res., 103(D9), 10,713-10,725.

Wang, J., A. A. Hoffman, R. J. Park, D. Jacob, and S. T. Martin (2008), Global distribution of solid and aqueous sulfate aerosols: Effect of the hysteresis of particle phase transitions, J. Geophys. Res., 113, D11206, doi:10.1029/2007JD009367.

Wesely, M. L. (1989), Parameterization of surface resistances to gaseous dry deposition in regional-scale numerical-models, Atmos. Environ., 23(6), 1293-1304, doi:10.1016/0004-6981(89)90153-4.

Wu, S. L., L. J. Mickley, D. J. Jacob, J. A. Logan, R. M. Yantosca, and D. Rind (2007), Why are there large differences between models in global budgets of tropospheric ozone?, J. Geophys. Res., 112(D5), D05302, doi:10.1029/2006JD007801.

Wu, S. L., L. J. Mickley, E. M. Leibensperger, D. J. Jacob, D. Rind, and D. G. Streets (2008), Effects of 2000-2050 global change on ozone air quality in the United States, J. Geophys. Res., 113, D06302, doi:10.1029/2007JD008917.

Yienger, J. J., and H. Levy (1995), Empirical-model of global soil-biogenic $\mathrm{NO}_{x}$ emissions, J. Geophys. Res., 100(D6), 11,447-11,464.

Yu, S. C., R. Dennis, S. Roselle, A. Nenes, J. Walker, B. Eder, K. Schere, J. Swall, and W. Robarge (2005), An assessment of the ability of threedimensional air quality models with current thermodynamic equilibrium models to predict aerosol $\mathrm{NO}_{3}^{-}, J$. Geophys. Res., 110, D07S13, doi:10.1029/2004JD004718.

Zhang, L. M., S. L. Gong, J. Padro, and L. Barrie (2001), A size-segregated particle dry deposition scheme for an atmospheric aerosol module, Atmos. Environ., 35(3), 549-560, doi:10.1016/S1352-2310(00)00326-5.

D. K. Henze, Goddard Institute for Space Studies, Columbia University, 2880 Broadway, New York, NY 10025, USA. (dkh2114@columbia.edu)

D. J. Jacob and L. J. Mickley, School of Engineering and Applied Sciences and Department of Earth and Planetary Sciences, Harvard University, Pierce Hall, 29 Oxford Street, Cambridge, MA 02138, USA. (djacob@fas.harvard.edu; mickley@fas.harvard.edu)

H. Liao, State Key Laboratory of Atmospheric Boundary Layer Physics and Atmospheric Chemistry, Institute of Atmospheric Physics, Chinese Academy of Sciences, Beijing 100029, China. (hongliao@mail.iap.ac.cn)

H. O. T. Pye and J. H. Seinfeld, Department of Chemical Engineering, California Institute of Technology, 1200 East California Boulevard, Mail Code 210-41, Pasadena, CA 91125, USA. (havala@caltech.edu; seinfeld@ caltech.edu)

S. Wu, Michigan Technological University, 1400 Townsend Drive, Houghton, MI 49931, USA. (wu18@fas.harvard.edu) 